\title{
Assessment of the Buildings Sector Efficiency Resource for the City of Plzen, Czech Republic
}

Prepared by

Pacific Northwest National Laboratory

Tecogen

SEVEn

Prepared: November 1995

Printed June 1996

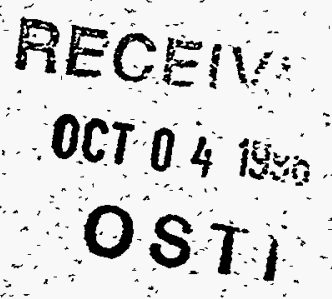

\section{FIN Global $\because$ Studies H Program}

Pacific Northwest National Laboratory Advanced International Studies

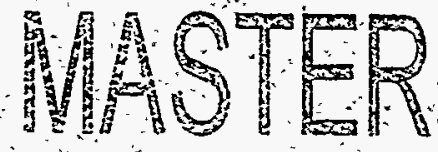




\section{DISCLAIMER}

This report was prepared as an account of work sponsored by an agency of the United States Government. Neither the United States Government nor any agency thereof, nor Battelle Memorial Institute, nor any of their employees, makes any warranty, express or implied, or assumes any legal liability or responsibility for the accuracy, completeness, or usefulness of any information, apparatus, product, or process disclosed, or represents that its use would not infringe privately owned rights. Reference herein to any specific commercial product, process, or' service by trade name, trademark, manufacturer, or otherwise does not necessarily. constitute or imply its endorsement, recommendation, or favoring by the United States Government or any agency thereof; or Battelle Memórial Institute. The views and opinions of authors expressed herein do not necessarily state or reflect those of the United States Government or any agency thereof.

\section{PACIFIC NORTHWEST NATIONAL LABORATORY operated by \\ BATTELLE. \\ for the \\ UNITED STATES DEPARTMENT OF ENERGY under Contract DE-ACO6-76RLO 1830}




\section{DISCLAIMER}

Portions of this document may be illegible in electronic image products. Images are produced from the best available original document. 
Assessment of the Buildings Sector Efficiency

Resource for the City of Plzeñ, Czech Republic

Prepared by

Pacific Northwest National Laboratory

Tecogen, Inc.

SEVEn

June 1996

Prepared for the U.S. Department of Energy under Contract DE-AC06-76RLO 1830

Pacific Northwest National Laboratory

Washington, DC 20024 


\section{Acknowledgments}

Gratitude is expressed to Len Rogers, U.S. Agency for International Development (AID), and Elaine Guthrie, Department of Energy (DOE), for making this study possible. Special thanks to Jirka Zeman at SEVEn, the Czech Center for Energy Efficiency, for leading the Czech effort; and Andrew Popelka at Tecogen and Steve Shankle at the Pacific Northwest National Laboratory (PNNL) for their technical support and oversight. Recognition is given to Bill Chandler, Director of PNNL's Advanced .International Studies Unit, for his foresight in establishing SEVEn and his guidance in this effort. 


\section{Summary}

The City of Plzen in the Czech Republic is considering options for providing energy services to its citizens in order to lower their energy bills and reduce pollution created by the burning of low quality brown coal. The U.S. Agency for International Development (AID), under the Support for Eastern European Democracy (SEED) program, agreed to fund an assessment of the space and water heat efficiency potential in the buildings sector in the City of Plzen. The assessment was funded through the U.S. Department of Energy's (DOE) Office of Energy Efficiency and Renewable Energy (EE) and conducted by the Pacific Northwest National Laboratory (PNNL) and its subcontractors, Tecogen, a U.S.-based energy research and development firm, and SEVEn, the Czech Center for Energy Efficiency.

The purpose of this assessment is to develop information on the energy efficiency potential in the buildings sectors. City management will use this information to support decisions on the provision of energy services to Plzeñ's citizens. In support of this purpose, specific objectives of this effort are

- To characterize baseline space and water heat energy use and efficiency potential that exists in the residential and non-residential buildings sectors in the municipality of Plzen.

- To develop capability in Czech organizations to conduct energy assessments modeled after procedures employed in the U.S. to support energy efficiency resource acquisitions.

This effort is not intended to provide a definitive analysis to enable selection of specific technologies for application, but to identify the major areas of efficiency potential and cost-effectiveness.

Subject to the data limitations and assumptions made, a significant efficiency resource exists in the space and water heating end-uses in the residential and non-residential buildings sectors. At current prices, this resource amounts to $27 \%$ of total buildings sector space and water heat energy consumption and increases to $29 \%$ and $34 \%$ of buildings sector consumption in two scenarios in which energy price controls and subsidies are relaxed.

About $84 \%$ of the efficiency resource resides in the district heating area at current fuel prices; this drops to $80 \%$ and $67 \%$ of the efficiency resource in the low and high price scenarios. Space and hot water heat provided by gaseous fuels is the next largest resource, increasing from $14 \%$ of the resource under current prices to $17 \%$ and $20 \%$ in the low and high price scenarios. While coal consumption for local boiler and on-site consumption is expected to increase significantly, it accounts for less than $2 \%$ of the total efficiency resource under the high fuel price scenario. Under the high price scenario, the coalbased efficiency resource increases to about $13 \%$ of the total resource. The electricity-based efficiency resource is the least sensitive to fuel prices and amounts to less than $1 \%$ of the total efficiency resource in all price scenarios.

Nearly $80 \%$ of the residential sector efficiency resource is in the high-rise multi-family building types, and of this, $98 \%$ is in the district heating area under current fuel prices. Under the high fuel price scenarios, about $70 \%$ of the residential sector efficiency resource is in the high rise building types, of which $90 \%$ is in the district heating area. In the non-residential sector, about $65 \%$ of the efficiency potential resides in the education, office and retail building types under all three fuel price scenarios. 
The share of the efficiency in district heat for these three types combined is $83 \%, 80 \%$ and $68 \%$ for the 1993, low and high fuel price scenarios, respectively.

The combination of the high-rise multi-family, education, office, and retail building types served by district heat contains over $60 \%$ of the total buildings sector space and water heat efficiency potential under the current and low fuel price scenarios; this decreases to about $50 \%$ in the high price scenario. Acquisition of this potential alone would result in about a $17 \%$ reduction in total buildings sector space and water heat energy consumption in all three fuel price scenarios and a $30 \%$ reduction in buildings sector space and water heat provided by district heat.

The levelized energy cost of the total efficiency resource is about 74 Crowns/gigajoule (Kc/GJ) compared to the current consumption weighted average energy price of $103 \mathrm{Kc} / \mathrm{GJ}$. At the low and high consumption weighted prices of $152 \mathrm{Kc} / \mathrm{GJ}$ and $286 \mathrm{Kc} / \mathrm{GJ}$ in the low and high price scenarios, the residential sector levelized energy cost is $75 \mathrm{Kc} / \mathrm{GJ}$ and $79 \mathrm{Kc} / \mathrm{GJ}$, respectively. Under current prices, the levelized energy cost of the efficiency resource within the district system fuel type is about $79 \mathrm{Kc} / \mathrm{GJ}$ compared to $136 \mathrm{Kc} / \mathrm{GJ}$ for district heat. Under the respective low and high price scenarios, district heat is projected to increase to $200 \mathrm{Kc} / \mathrm{GJ}$ and $350 \mathrm{Kc} / \mathrm{GJ}$ compared to a levelized energy cost for the district heat based efficiency resource of $80 \mathrm{Kc} / \mathrm{GJ}$.

Under two future consumption scenarios and in absence of actions to acquire energy efficiency, buildings sector space and water heat energy consumption is projected to increase by $1 \%$ and $6 \%$ overall by the year 2003. Depending upon changes in fuel prices, future buildings sector space and water heat energy consumption could decrease approximately $22 \%$ to $34 \%$ if the entire resource were acquired.

With respect to the second major objective of developing in-country expertise, the Czech team led by SEVEn participated in all aspects of the study with the U.S. participants serving primarily in an advisory capacity. It is felt that assessment capabilities were successfully transferred to the Czech study participants and the process and results were well received by the City staff. 


\section{Contents}

Acknowledgments $: \ldots \ldots \ldots \ldots \ldots \ldots \ldots \ldots \ldots \ldots \ldots \ldots \ldots \ldots \ldots \ldots$ iii

Summary $\ldots \ldots \ldots \ldots \ldots \ldots \ldots \ldots \ldots \ldots \ldots \ldots \ldots \ldots \ldots \ldots \ldots \ldots$

1.0 Introduction $\ldots \ldots \ldots \ldots \ldots \ldots \ldots \ldots \ldots \ldots \ldots \ldots \ldots \ldots \ldots \ldots \ldots \ldots$

1.1 Scope and Approach $\ldots \ldots \ldots \ldots \ldots \ldots \ldots \ldots \ldots \ldots \ldots \ldots \ldots$

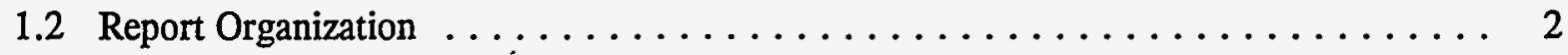

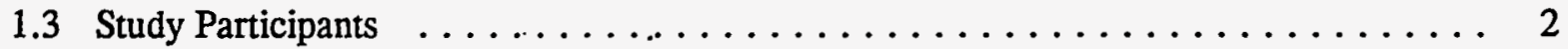

2.0 Energy Use Baseline and Demand Forecast $\ldots \ldots \ldots \ldots \ldots \ldots \ldots \ldots \ldots \ldots \ldots \ldots$

2.1 Sector and Subsector Definitions $\ldots \ldots \ldots \ldots \ldots \ldots \ldots \ldots \ldots \ldots \ldots \ldots \ldots \ldots \ldots$

2.1.1 Residential Sector $\ldots \ldots \ldots \ldots \ldots \ldots \ldots \ldots \ldots \ldots \ldots \ldots \ldots \ldots \ldots$

2.1 .2 Non-Residential Sector $\ldots \ldots \ldots \ldots \ldots \ldots \ldots \ldots \ldots \ldots \ldots$

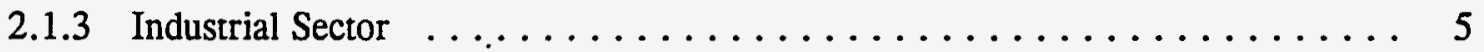

2.2 Thermal Energy Consumption Baseline $\ldots \ldots \ldots \ldots \ldots \ldots \ldots \ldots$

2.2.1 Heat and Hot Water Consumption $\quad \ldots \ldots \ldots \ldots \ldots \ldots \ldots$

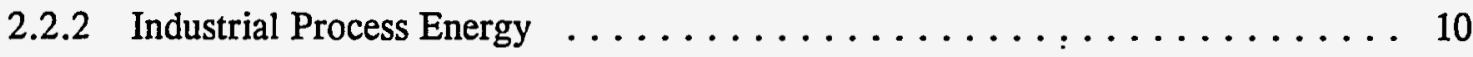

2.3 Scenario Assumptions $\ldots \ldots \ldots \ldots \ldots \ldots \ldots \ldots \ldots \ldots \ldots \ldots \ldots \ldots$

3.0 Buildings Sector Efficiency Assessment $\ldots \ldots \ldots \ldots \ldots \ldots \ldots \ldots \ldots$

3.1 Efficiency Measures $\ldots \ldots \ldots \ldots \ldots \ldots \ldots \ldots \ldots \ldots \ldots \ldots \ldots \ldots$

3.1.1 Efficiency Measures Considered $\ldots \ldots \ldots \ldots \ldots \ldots \ldots \ldots \ldots \ldots$

3.1.2 Efficiency Measures Not Considered $\ldots \ldots \ldots \ldots \ldots \ldots \ldots$

3.1.3 Summary of Efficiency Measures Considered $\ldots \ldots \ldots \ldots \ldots$

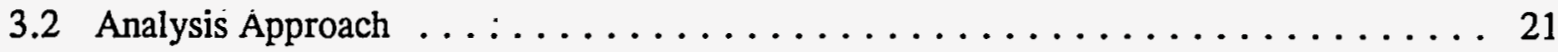

3.2.1 Technical Analysis Method $\ldots \ldots \ldots \ldots \ldots \ldots \ldots \ldots \ldots \ldots \ldots$

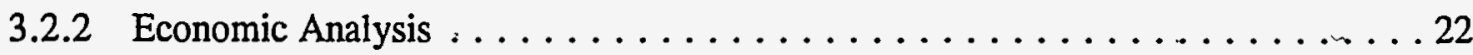


3.3 Buildings Sector Efficiency Assessment Results $\ldots \ldots \ldots \ldots \ldots \ldots \ldots \ldots$

3.3.1 Baseline Efficiency Assessment . . . . . . . . . . . . . . 26

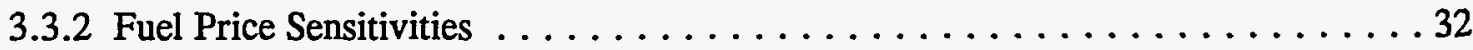

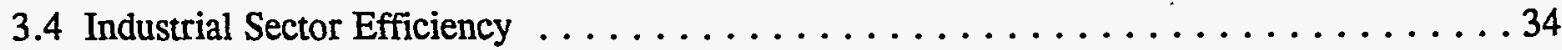

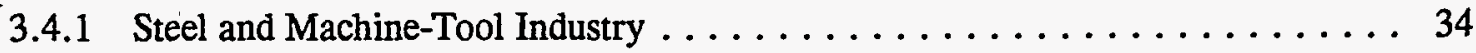

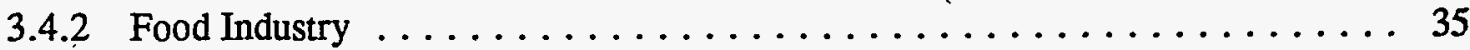

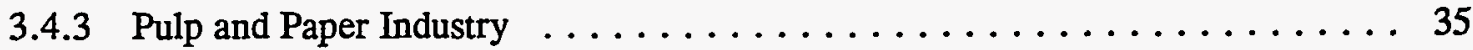

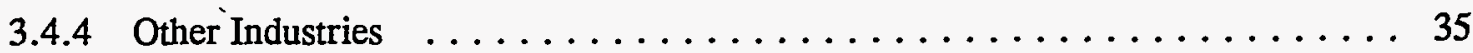

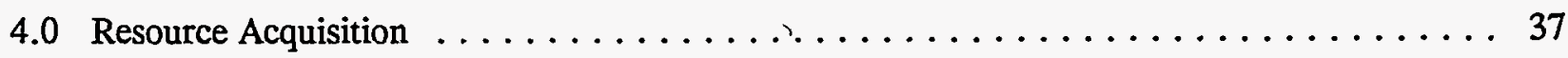

4.1 Resource Acquisition Barriers $\ldots \ldots \ldots \ldots \ldots \ldots \ldots \ldots \ldots \ldots \ldots$

4.1.1 Tenant Responsible for Energy Bill $\ldots \ldots \ldots \ldots \ldots \ldots \ldots \ldots \ldots$

4.1 .2 Tenant Time Horizons $\ldots \ldots \ldots \ldots \ldots \ldots \ldots \ldots \ldots \ldots \ldots \ldots$

4.1.3 Insufficient Information $\ldots \ldots \ldots \ldots \ldots \ldots \ldots \ldots \ldots \ldots \ldots$

4.1 .4 Lack of Capital $\ldots \ldots \ldots \ldots \ldots \ldots \ldots \ldots \ldots \ldots \ldots \ldots$

4.1.5 Lack of Individual Matters $\ldots \ldots \ldots \ldots \ldots \ldots \ldots \ldots \ldots \ldots$

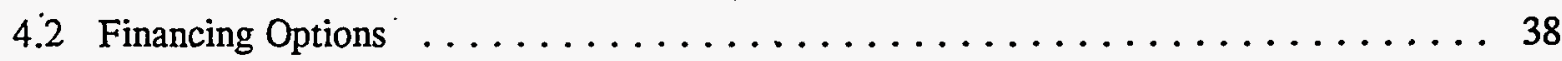

4.2 .1 Utility-Financed DSM $\ldots \ldots \ldots \ldots \ldots \ldots \ldots \ldots \ldots \ldots \ldots \ldots$

4.2.2 Third-Party Contracting $\ldots \ldots \ldots \ldots \ldots \ldots \ldots \ldots \ldots \ldots \ldots \ldots \ldots \ldots$

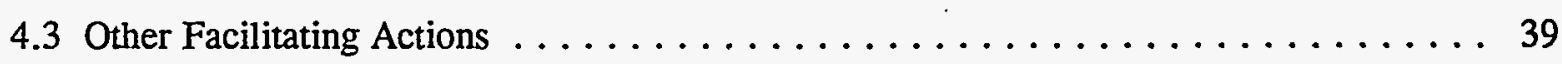

4.3.1 Information Resource $\ldots \ldots \ldots \ldots \ldots \ldots \ldots \ldots \ldots \ldots \ldots \ldots \ldots$

4.3.2 Private Business Activities $\ldots \ldots \ldots \ldots \ldots \ldots \ldots \ldots \ldots \ldots \ldots \ldots \ldots$

4.3 .3 Policy Changes . . . . . . . . . . . . . . . . . . 39

viii 


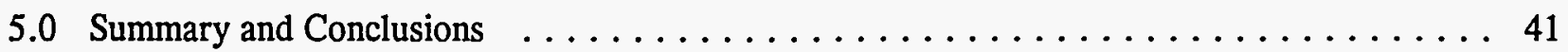

5.1 Baseline Thermal Energy Consumption $\ldots \ldots \ldots \ldots \ldots \ldots \ldots \ldots$

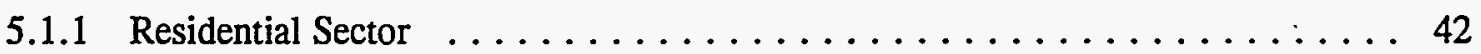

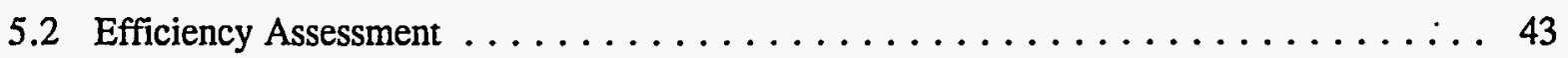

5.3 Resource Acquisition Issues $\ldots \ldots \ldots \ldots \ldots \ldots \ldots \ldots \ldots \ldots \ldots \ldots \ldots \ldots$

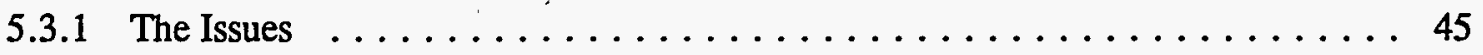

5.3 .2 Addressing the Issues $\ldots \ldots \ldots \ldots \ldots \ldots \ldots \ldots \ldots \ldots \ldots$

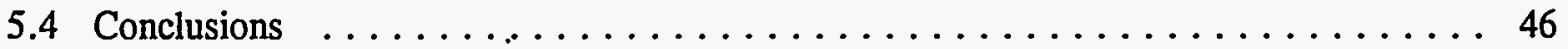

6.0 Related Publications . . . . . . . . . . . . . . . . . . . . . . 49 


\section{Tables}

2.1 Estimated Number of Residential Buildings by Type and Heated Square Meters _. . . . . 4

2.2 Total Primary Fuel Input for the Production of Heat Energy, $1989 \ldots \ldots \ldots \ldots$

2.3 Primary Heat Energy Fuel Consumption by Function, $1989 \ldots \ldots \ldots \ldots \ldots$

2.4 Space and Water Heat Energy Consumption by Fuel Type, Heating Equipment Type

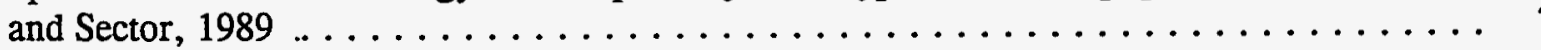

2.5 Residential Sector Space Heat Energy Consumption by Fuel Type, Heating Equipment Type and Subsector, $1989 \ldots \ldots \ldots \ldots \ldots \ldots \ldots \ldots \ldots \ldots \ldots$

2.6 Residential Sector Water Heat Energy Consumption by Fuel Type, Heating Equipment Type and Subsector, $1989 \ldots \ldots \ldots \ldots \ldots \ldots \ldots \ldots \ldots \ldots \ldots$

2.7 Non-Residential Sector Space and Water Heat Energy Consumption by Fuel Type, Heating Equipment Type and Subsector in $1989 \ldots \ldots \ldots \ldots \ldots \ldots \ldots \ldots \ldots \ldots \ldots$

2.8 Industrial Sector Heat Energy Consumption by Fuel Type, Equipment Type, and

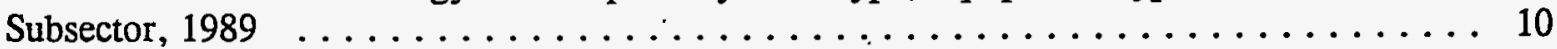

3.1 Efficiency Measures Considered and Estimated Per Unit Cost and Lifetime $\ldots \ldots \ldots$

3.2 Base Economic Assumptions for Analysis of Efficiency Measures . . . . . . . . . . . . . 24

3.3 Fuel Price Levels Used to Drive Analysis of Efficiency Resource by Fuel and

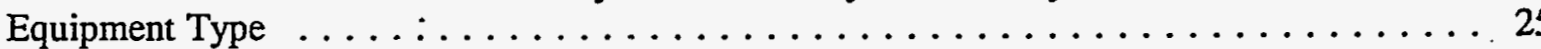

3.4 Residential Sector Cost-Effective Space and Water Heat Efficiency Resource by Building, Fuel and Equipment Type Using Base Assumptions and Fuel Prices, 1993

3.5. Economic Analysis Results of Residential Sector Cost-Effective Energy Efficiency Resource

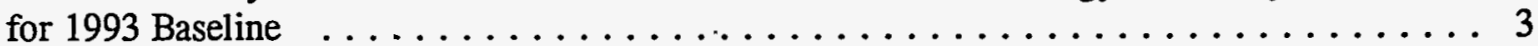

3.6 Estimated Non-Residential Space and Water Heat Efficiency Potential by Fuel and Heating System Type, $1993 \ldots \ldots \ldots \ldots \ldots \ldots \ldots \ldots \ldots \ldots \ldots \ldots \ldots$

3.7 Residential Sector Efficiency Resource for Base and Alternate Fuel Price Scenarios, $1993 \quad \ldots 32$

3.8 Residential Sector Cost-Effective Efficiency Resource by Fuel Price Scenario and Fuel and Heating Equipment Type

3.9 Non-Residential Sector Cost-Effective Efficiency Résource by Fuel Price Scenario and Fuel and Heating Equipment Type 
5.1 Baseline Space and Water Heat Energy Consumption by Sector, Fuel Type and Equipment Type, 1989

5.2 Residential Sector Space and Water Heat Energy Consumption by Fuel and Equipment Type, 1989

5.3 Residential and Non-Residential Sector Space and Water Heat Efficiency Improvement by Fuel and Equipment Type for Current and Projected Fuel Prices and as a Percent of Total Residential and Non-Residential Consumption 


\subsection{Introduction}

The City of Plzeň in the Czech Republic is considering options for providing energy services to its citizens in order to lower their energy bills and reduce pollution created by. the burning of low quality brown coal. In the fall of 1992, the U.S. Agency for International Development (AID) under the Support for Eastern European Democracy (SEED) program, agreed to fund an assessment of the options for providing heating energy to the buildings sector in the City of Plzen.

AID entered into an interagency agreement with the U.S. Department of Energy's (DOE) Office of Energy Efficiency and Renewable Energy (EE) and Office of Fossil Energy (FE) to provide the needed assistance. EE and FE were assigned responsibility for the demand- and supply-side assessments, respectively. In addition, EE was assigned the lead for integrating the demand-and supply-side assessments to provide the combinations of energy efficiency and supply resources in order to meet the heating requirements of Plzeň's buildings sector, given cost and environmental considerations.

This report documents the assessment of the buildings sector efficiency resource conducted by the Pacific Northwest National Laboratory (PNNL) and its subcontractors, Tecogen, a U.S.-based energy research and development firm, and SEVEn, the Czech Center for Energy Efficiency. The supply resource assessment conducted by Gilbèrt-Commonwealth, Inc., an engineering consulting firm, was developed concurrently. PNNL has responsibility for the integration of the efficiency and supply resource assessments.

\subsection{Scope and Approach}

The purpose of this assessment is to develop information on buildings sector energy efficiency potential needed by City management to support decisions on the provision of energy services to Plzeň's citizens. In support of this purpose, specific objectives of this effort are

- To characterize baseline space and water heat energy use and efficiency potential that exists in the residential and non-residential buildings sectors in the municipality of Plzeñ.

- To develop capability in Czech organizations to conduct energy assessments modeled after procedures employed in the U.S. to support energy resource acquisitions.

This effort is not intended to provide a definitive analysis to enable selection of specific technologies for application.

The baseline energy-use characterization segments the residential and non-residential building stock into individual building types and estimates the space and water heat energy consumption by each building type, fuel type, and equipment type. The efficiency potential is then estimated for each building, fuel and equipment type based upon cost-effectiveness criteria. Major considerations for the acquisition of the efficiency resource are identified; it is anticipated these will be pursued subsequent to this assessment.

A key aspect of the effort is to build the capability in Czech organizations and individuals for conducting subsequent assessments employing integrated resource planning principles used by the U.S. 
utility industry. To this end, Czech organizations and experts participated in all aspects of the study with the U.S. participants serving primarily in an advisory capacity.

\subsection{Report Organization}

This report summarizes the detailed assessment that was written in Czech and is organized into the following five chapters:

- Chapter 2 provides the baseline and forecast of the demand for thermal energy consumed to provide space and water heat.

- Chapter 3 presents the efficiency resource options considered and the estimated efficiency resource.

- Chapter 4 discusses approaches and issues for consideration for the acquisition of the buildings sector efficiency resource.

- Chapter 5 presents the summary and conclusions.

For readers interested in converting the energy and currency units to British Thermal Units (Btu) and dollars, one gigajoule (GJ) equals one million Btu and about 28 Czech Koruna (Kc) equals one U.S. dollar.

\subsection{Study Participants}

The Pacific Northwest National Laboratory, one of DOE's five multi-program research laboratories, conducts a significant number of programs in the area of energy efficiency and integrated resource planning. PNNL's Advanced International Studies Unit (AISU) conducts research on global climate change and manages cooperative programs to transfer energy-efficiency practices and technologies to other countries. PNNL provided the technical and management oversight for this effort.

PNNL/AISU contracted with the U.S. firm Tecogen and the Czech Center for Energy Efficiency (SEVEn) to support the demand-side and integrated assessment activities. Tecogen, a subsidiary of Thermo Electron Corporation, specializes in the development and manufacture of gas-fired cogeneration and cooling equipment and has significant experience in energy demand assessment and field evaluation of energy-producing and -consuming systems. Tecogen conducted the assessment of demand-side resource opportunities and provided technical support for the integration of the demand and supply resources.

SEVEn is a Czech non-governmental, non-profit organization dedicated to improving economic development and the environment through energy efficiency. SEVEn provided the Czech lead for the demand-side assessment activities and the interface to the City of Plzen for project communications, and represented the study recommendations to the City and other organizations. SEVEn engaged the. expertise of Mr. Martin Pys, the Energy Service Company, and EnergoCentrum. 


\subsection{Energy Use Baseline and Demand Forecast}

An estimate of baseline thermal energy use and future demand underlies the analysis of the efficiency resource in this assessment. Section 2.1 contains the sectors defined for the analysis and estimates for the residential building stock and floorspace. Section 2.2 provides the baseline thermal energy use for the entire City by fuel form, sector and major end-use (heating, hot water and process energy). Projected growth in energy consumption through the year 2003 is discussed in Section 2.3.

\subsection{Sector and Subsector Definitions}

Three sectors were defined for allocating the consumption of thermal energy: residential, nonresidential and industrial. Subsectors within each sector were then defined and floorspace estimates within the residential sector were developed to support the analysis of efficiency potential.

\subsubsection{Residential Sector}

The urban district--of which there are 94--was selected as the level of analysis for estimating residential floorspace and building type as this is the smallest territory for which building type data is available from the Federal Statistical Office and the Plzen Municipal Information System. In cooperation with staff from the Plzeň Department of Planning and Development, 11 residential building types were specified as follows:

$\begin{array}{ll}\text { Res-1 } & 300-400 \text { year old houses } \\ \text { Res-2 } & 150-180 \text { year old houses } \\ \text { Res-3 } & \text { Houses from the beginning of the 20th century } \\ \text { Res-4 } & \text { Villa houses from the 1930s } \\ \text { Res-5 } & \text { One-floor detached houses } \\ \text { Res-6 } & \text { Two-floor detached houses } \\ \text { Res-7 } & \text { Cooperative buildings from the 1950s and 60s } \\ \text { Res-8 } & \text { Eight-floor pre-fab houses PS 69, type } 324 \text { (before 1981) } \\ \text { Res-9 } & \text { Eight-floor pre-fab houses PS 69, type } 324 \text { (after 1981) } \\ \text { Res-10 } & \text { Eight-floor pre-fab houses PS 69, type } 34143 \text { (before 1981) } \\ \text { Res-11 } & \text { Eight-floor pre-fab houses T06 B }\end{array}$

The estimated number of residential buildings and heated square meters by building type for the City of Plzeñ are shown in Table 2.1.

Considerable discrepancies existed in the floorspace estimates within certain urban districts. These discrepancies were resolved in consultation with staff from the Plzeň Department of Planning and Development.

These data indicate that about $50 \%$ of residential heated floorspace is in the pre-fab high-rise multifamily housing types (Res 8-11) and another 7\% is the multi-family cooperative type (Res-7). Detached housing (Res $5-6$ ) accounts for about $16 \%$ of heated floorspace, with the remaining $26 \%$ accounted for by the four building types dating from the early 1930's and before. 
Table 2.1. Estimated Number of Residential Buildings by Type and Heated Square Meters

\begin{tabular}{|c|c|c|c|}
\hline Group & $\begin{array}{c}\text { Number of } \\
\text { Buildings }\end{array}$ & Heated $\mathbf{m}^{2}$ & $\%$ of $\mathrm{m}^{2}$ \\
\hline Res-1 & 137 & 56,370 & 1 \\
\hline Res-2 & 1,177 & 392,287 & 8 \\
\hline Res-3 & 1,120 & 718,741 & 14 \\
\hline Res-4 & 377 & 142,347 & 3 \\
\hline Res-5 & 5,851 & 464,088 & 9 \\
\hline Res-6 & 2,218 & 364,716 & 7 \\
\hline Res-7 & 706 & 334,522 & 7 \\
\hline Res-8 & 605 & 836,628 & 17 \\
\hline Res-9 & 289 & 399,284 & 8 \\
\hline Res-10 & 80 & 180,560 & 4 \\
\hline Res-11 & 1,060 & $1,123,488$ & 22 \\
\hline Total & 13,620 & $5,013,031$ & 100 \\
\hline
\end{tabular}

\subsubsection{Non-Residential Sector}

The seven building types identified in the non-residential sector are as follows:

NonRes-1 Education (primary, secondary schools, universities)

NonRes-2 Health Institutions (including nursery schools)

NonRes-3 Gymnasium

NonRes-4 Office/Administration

NonRes-5 Retail Services

NonRes-6 Accommodation

NonRes-7 Culture

Data limitations coupled with time and budget limitations did not permit a comparable characterization of the non-residential building stock. 


\subsubsection{Industrial Sector}

Five major types of industrial activity were specified for the analysis as follows:

Ind-1 Machine Tool Industry and Steel Production

Ind-2 Building Material Production

Ind-3 Paper Industry

Ind-4 Agricultural Production

Ind-5 Food Processing Industry

\subsection{Thermal Energy Consumption Baseline}

This section describes the consumption of thermal energy within the municipality of Plzen. The year 1989 was selected for the base year because it was the most recent year for which a weather tape was available to drive the simulations for estimating end-use consumption levels and the performance of applicable efficiency measures. Consumption is provided by major fuel form (district heat and solid, liquid and gaseous fuels) and defined sector and subsector.

Data on delivered energy were often limited in quantity and quality, which required estimation based on calculations and assumptions. Consumption data for each fuel type were developed as follows:

- Solid fuel consumption was estimated from limited delivery data augmented by assumption and calculation.

- Liquid fuel consumption was based on data from the REZZO emissions sources data base maintained by the Ministry of Environment and from Benzina, the state-owned company responsible for liquid fuels.

- District heat energy consumption was developed from data provided by CHSS, the municipal heat transmission and distribution company; ZCE, the West Bohemia Electric Company; and TEZA, the municipal district heat supply company. These data reflect the estimated consumption for which customers are billed; this consumption is based upon heated floor area and other customer characteristics.

- Electricity consumption data are available from metered consumption records for individual customers; each living unit is metered separately. These data include several end-uses, which may include heating and hot water, so estimation was required to develop space and water heat consumption.

- Gaseous fuels consumption data were obtained from the West Bohemia Gasworks, which meters deliveries for nearly every customer.

Table 2.2 provides the fuel input to major type of conversion unit and process for the production of heat energy in Plzeñ. On-site consumption refers to the conversion of fuel to heat and/or hot water within the individual living space, be it a single or multi-family dwelling. Boiler plant consumption refers to 586 distributed boilers located in the city, each serving a single building or a group of buildings. CHSS consumption refers to either the central or distributed boilers serving the CHSS systems. 
Table 2.2. Total Primary Fuel Input for the Production' of Heat Energy, 1989

\begin{tabular}{||l|r|r|r|r|r||}
\hline \hline Place of Consumption & $\begin{array}{c}\text { Solid Fuels } \\
\text { (GJ) }\end{array}$ & $\begin{array}{c}\text { Liquid } \\
\text { Fuels (GJ) }\end{array}$ & $\begin{array}{c}\text { Gaseous } \\
\text { Fuels (GJ) }\end{array}$ & Total (GJ) & (\%) \\
\hline \hline On-site & 857,212 & 0 & $1,157,834$ & $2,015,046$ & 10 \\
\hline Boiler plants & $1,450,050$ & 585,247 & $2,323,767$ & $4,359,064$ & 21 \\
\hline CHSS Sources & $14,341,440$ & 149,645 & 0 & $14,491,085$ & 69 \\
\hline Totals (GJ) & $16,648,702$ & 734,892 & $3,481,601$ & $20,865,195$ & \\
\hline$(\%)$ & 80 & 3 & 17 & & 100 \\
\hline
\end{tabular}

This shows that approximately $70 \%$ of the heating energy is consumed in the CHSS system and that $80 \%$ of the heating energy is in the form of solid fuels, primarily coal.

The 20.9 million GJ of primary energy consumed to produce thermal energy is accounted for by major function as shown in Table 2.3.

Table 2.3. Primary Heat Energy Fuel Consumption by Function, 1989

\begin{tabular}{|c|c|}
\hline Function & $\begin{array}{c}\text { Consumption } \\
\text { (thousand GJ) }\end{array}$ \\
\hline \hline Heat and Hot Water & \\
\hline Residential & 3,047 \\
\hline Non-Residential & 1,769 \\
\hline Industrial & 3,038 \\
\hline Total & 7,854 \\
\hline Process & 4,041 \\
\hline Industrial & 207 \\
\hline Other & 4,248 \\
\hline Total & 675 \\
\hline Electricity Production & \\
\hline Losses & 6,417 \\
\hline CHSS & 1,565 \\
\hline Other & 7,982 \\
\hline Total & 20,865 \\
\hline Total & \\
\hline
\end{tabular}


Of total primary energy consumption used to provide thermal energy, about $38 \%$ provides space and water heat, $20 \%$ meets process energy requirements, $38 \%$ is lost in conversion and transmission/ distribution losses, and about $3 \%$ goes to electricity generation. Losses for the production and transmission of district heat amount to about $44 \%$ of total energy input to generate district heat. Conversion losses for local consumption and boilers amount to about $25 \%$ of their total combined energy input. Discussion of heat and hot water energy and process energy use follows in the next two subsections.

\subsubsection{Heat and Hot Water Consumption}

Energy consumption for heating and hot water use by fuel type and heating equipment type is shown in Table 2.4 for the three sectors. Nearly $40 \%$ of heat and hot water energy use is accounted for by the residential sector, about $22 \%$ by the non-residential buildings sector, and $40 \%$ by the industrial sector. District heat is the major energy source for heat and hot water at $64 \%$ of the total, followed by building boilers supplying at $18 \%$, and individual home heating equipment at nearly $17 \%$.

Table 2.4. Space and Water Heat Energy Consumption by Fuel Type, Heating Equipment Type and Sector, 1989

\begin{tabular}{|c|c|c|c|c|c|c|c|c|c|}
\hline \multirow[b]{2}{*}{ Group } & \multicolumn{2}{|c|}{ On-Site } & \multicolumn{2}{|c|}{ Boiler Plants } & \multirow[b]{2}{*}{$\begin{array}{l}\text { Gas } \\
\text { Fuels } \\
\text { (GJ) }\end{array}$} & \multirow[b]{2}{*}{$\begin{array}{c}\text { CHSS } \\
\text { (GJ) }\end{array}$} & \multirow[b]{2}{*}{$\begin{array}{l}\text { Electr. } \\
\text { Energy } \\
\text { (GJ) }\end{array}$} & \multirow[b]{2}{*}{$\begin{array}{l}\text { Total } \\
\text { (GJ) }\end{array}$} & \multirow[b]{2}{*}{$(\%)$} \\
\hline & $\begin{array}{l}\text { Solid } \\
\text { Fuels } \\
\text { (GJ) } \\
\end{array}$ & $\begin{array}{c}\text { Gas } \\
\text { Fuels } \\
\text { (GJ) } \\
\end{array}$ & $\begin{array}{l}\text { Solid } \\
\text { Fuels } \\
\text { (G.J) } \\
\end{array}$ & $\begin{array}{c}\text { Liquid } \\
\text { Fuels } \\
\text { (GJ) } \\
\end{array}$ & & & & & \\
\hline Res & 318,169 & 633,912 & 233,275 & 0 & 108,690 & $1,673,465$ & 79,884 & $3,047,395$ & 38.80 \\
\hline NonRes & 92,987 & 184,831 & 238.944 & 2,653 & 236,679 & 994,823 & 17,739 & $1,768,655$ & 22.5 \\
\hline Ind & 46,493 & 25,538 & 176,989 & 129,475 & 290,239 & $2,359,975$ & 8,870 & $3,037,579$ & 38.69 \\
\hline $\begin{array}{l}\text { Totals } \\
\text { (GJ) }\end{array}$ & 457,649 & 844,281 & 649,208 & 132,128 & 635,608 & $5,028,263$ & 106,493 & $7,853,629$ & \\
\hline$(\%)$ & 5.83 & 10.75 & 8.27 & 1.68 & 8.09 & 64.02 & 1.36 & & 100.00 \\
\hline
\end{tabular}

\section{Residential Sector}

Residential sector space and water heat end-uses are shown in Tables 2.5 and 2.6 , respectively, by fuel type and equipment type for each of the 11 identified building types. Space heat accounts for nearly $80 \%$ of the total energy used for residential heat and hot water energy consumption.

The four high-rise building types account for about $55 \%$ of space heat energy use and about $51 \%$ of the total floorspace, yielding the highest use intensity. These buildings are also predominantly served by district heat, which accounts for about $88 \%$ of their total estimated heat energy use and $90 \%$ of the residential sector space heat consumption supplied by district heat. The remainder of the residential building stock is served primarily by home heating equipment fired by solid fuel and gaseous fuels, 
Table 2.5. Residential Sector Space Heat Energy Consumption by Fuel Type, Heating Equipment Type and Subsector, 1989

\begin{tabular}{|c|c|c|c|c|c|c|c|c|c|}
\hline \multirow[b]{2}{*}{$\begin{array}{c}\text { Building } \\
\text { Group }\end{array}$} & \multicolumn{2}{|c|}{ On-Site } & \multicolumn{2}{|c|}{ Boiler Plants } & \multirow[b]{2}{*}{$\begin{array}{l}\text { CHSS } \\
\text { (GJ) }\end{array}$} & \multirow[b]{2}{*}{$\begin{array}{c}\text { Elect. } \\
\text { (GJ) }\end{array}$} & \multirow[b]{2}{*}{ Total (GJ) } & \multirow[b]{2}{*}{ Area $\left(\mathbf{m}^{2}\right)$} & \multirow[b]{2}{*}{$\begin{array}{c}\text { Specific } \\
\text { Cons. } \\
\left.\text { (GJ/m } \mathbf{m}^{2}\right) \\
\end{array}$} \\
\hline & $\begin{array}{c}\text { Solid } \\
\text { Fuels } \\
\text { (GJ) }\end{array}$ & $\begin{array}{c}\text { Gas } \\
\text { Fuels } \\
\text { (GJ) } \\
\end{array}$ & $\begin{array}{c}\text { Solid } \\
\text { Fuels } \\
\text { (G.) }\end{array}$ & $\begin{array}{c}\text { Gas } \\
\text { Fuels } \\
\text { (GJ) } \\
\end{array}$ & & & & & \\
\hline Res-1 & 16,157 & 9,854 & 0 & 0 & 0 & 644 & 26,655 & 56,370 & 0 \\
\hline Res-2 & 41,623 & 68,990 & 3,995 & 17,616 & 7,258 & 4,829 & 144,311 & 392,287 & 0 \\
\hline Res-3 & 19,445 & 121,252 & 50,822 & 15,273 & 70,150 & 6,117 & 283,059 & 718,741 & 0 \\
\hline Res-4 & 15,445 & 46,368 & 0 & 1,220 & 0 & 2,575 & 65,608 & 142,347 & 0 \\
\hline Res-5 & 129,739 & 93,229 & 0 & 485 & 112 & 9,658 & 233,223 & 464,088 & 1 \\
\hline Res-6 & 86,493 & 69,287 & 0 & 1 & 280 & 6,439 & 162,499 & 364,716 & 0 \\
\hline Res-7 & 9,267 & 69,532 & 5,882 & 23,075 & 51,682 & 1,932 & 161,371 & 334,522 & 0 \\
\hline Res-8. & 0 & 0 & 0 & 0 & 457,987 & 0 & 457,987 & 836,628 & 1 \\
\hline Res-9 & 0 & 0 & 0 & 0 & 235,101 & 0 & 235,101 & 399,284 & 1 \\
\hline Res-10 & 0 & 0 & 0 & 1,078 & 88,778 & 0 & 89,856 & 180,560 & 1 \\
\hline Res 11 & 0 & 20,197 & 116,591 & 23.856 & 393,449 & 0 & 554,093 & $1,123,488$ & 0 \\
\hline Total & 318,169 & 498,709 & 177,290 & 82,604 & $1,304,797$ & 32,194 & $2,413,763$ & $.5,013,031$ & 0 \\
\hline
\end{tabular}

Table 2.6. Residential Sector Water Heat Energy Consumption by Fuel Type, Heating Equipment Type and Subsector, 1989

\begin{tabular}{|c|c|c|c|c|c|c|}
\hline \multirow{2}{*}{ Building Group } & \multirow[b]{2}{*}{ Gas (GJ) } & \multicolumn{2}{|c|}{ Boiler Houses } & \multirow[b]{2}{*}{ CHSS (GJ) } & \multirow[b]{2}{*}{ Electricity (GJ) } & \multirow[b]{2}{*}{ Total (GJ) } \\
\hline & & Solid (GJ) & Gas (GJ) & & & \\
\hline Res-1 & 1,396 & 0 & 0 & 0 & 2,384 & 3.780 \\
\hline Res-2 & 10,450 & 1,262 & 5,563 & 2,051 & 6,200 & 25,525 \\
\hline Res-3 & 30,514 & 16,049 & 4,823 & 19,821 & 2,861 & 74,068 \\
\hline Res-4 & 18,409 & 0 & 385 & 0 & 2,385 & 21,180 \\
\hline Res-5 & 24,928 & 0 & 153 & 32 & 19,553 & 44,666 \\
\hline Res- 6 & 18,225 & 0 & $\mathbf{0}$ & 79 & 12,876 & 31,180 \\
\hline Res-7 & 25,282 & 1,858 & 7,287 & 14,603 & 1,431 & 50,460 \\
\hline Res-8 & 0 & 0 & 0 & 129,404 & 0 & 129,404 \\
\hline Res-9 & 0 & 0 & 0 & 66,427 & 0 & 66,427 \\
\hline Res-10 & 0 & 0 & 340 & 25,084 & 0 & 25,425 \\
\hline Res-11 & 5,998 & 36,818 & 7,534 & 111,168 & 0 & 161,518 \\
\hline Total & 135,202 & 55,987 & 26,085 & 368,669 & 47,690 & 633,632 \\
\hline
\end{tabular}


which account for $13 \%$ and $21 \%$ of total energy use, respectively. Local boilers account for about $10 \%$ of residential space heat energy consumption, with solid and gaseous fuels at $7 \%$ and $3 \%$ of the residential total, respectively. Only three building types are served to any extent by local boilers using solid and gaseous fuels-150-180 year old houses, multi-family houses dating from the beginning of the 20th century, and vintage cooperatives from the 1950 s and 60 s.

As with heat energy consumption, the four high rise building types account for the majority of energy use for hot water, accounting for $60 \%$ of the total hot water energy use. Of this amount, about $87 \%$ is provided by the district heating system and the remainder by natural gas and solid fuels, about $10 \%$ and $4 \%$, respectively. Following district heat at $58 \%$ of total hot water energy use, natural gas is second, accounting for about $25 \%$ of total energy use, and solid fuels and electricity are about equal at $8 \%$ each.

\section{Non-Residential Sector}

Estimated heat and hot water energy use in the non-residential sector is displayed in Table 2.7. Education, office, and retail service buildings account for about $65 \%$ of total non-residential sector use, followed by health and lodging buildings that account for another $22 \%$ of heat and hot water usage.

District heat accounts for about $56 \%$ of total heat and hot water use, with education and office buildings accounting for over half of this usage. Individual boilers provide the next largest share of heat and hot water, $27 \%$, which is split nearly equally between solid and gaseous fuels. Individual home heating equipment accounts for the remaining $16 \%$ of energy consumption, two-thirds of which is supplied by gaseous fuels.

Table 2.7. Non-Residential Sector Space and Water Heat Energy Consumption by Fuel Type, Heating Equipment Type and Subsector in 1989

\begin{tabular}{|c|c|c|c|c|c|c|c|c|c|}
\hline \multirow[b]{2}{*}{ Group } & \multicolumn{2}{|c|}{ On-site } & \multicolumn{3}{|c|}{ Boiler Plants } & \multirow[b]{2}{*}{$\begin{array}{c}\text { CHSS } \\
\text { (GJ) } \\
\end{array}$} & \multirow[b]{2}{*}{$\begin{array}{c}\text { Electr. } \\
\text { Energy } \\
\text { (GJ) }\end{array}$} & \multirow[b]{2}{*}{$\begin{array}{l}\text { Total } \\
\text { (GJ) } \\
\end{array}$} & \multirow[b]{2}{*}{$\%$} \\
\hline & $\begin{array}{c}\text { Solid } \\
\text { Fuels } \\
\text { (GJ) } \\
\end{array}$ & $\begin{array}{c}\text { Gas } \\
\text { Fuels } \\
\text { (GJ) } \\
\end{array}$ & $\begin{array}{c}\text { Solid } \\
\text { Fuels } \\
\text { (GJ) } \\
\end{array}$ & $\begin{array}{c}\text { Liquid } \\
\text { Fuels } \\
\text { (GJ) } \\
\end{array}$ & $\begin{array}{c}\text { Gas Fuels } \\
\text { (GJ) } \\
\end{array}$ & & & & \\
\hline NR1 & 23,247 & 22,189 & 56,718 & 0 & 45,422 & 353,771 & 4,435 & 505,783 & 28.6 \\
\hline NR2 & 11,639 & 6,840 & 8,590 & 0 & 43,178 & 118,190 & 2,424 & 190,861 & 10.8 \\
\hline NR3 & 5,279 & 8,614 & 23,025 & 1,022 & 11,255 & 24,207 & 809 & 74,210 & 4.2 \\
\hline NR4 & 16,374 & 36,286 & 46,279 & 0 & 24,939 & 180,388 & 3,000 & 30,7266 & 17.4 \\
\hline NR5 & 18,496 & 96,743 & 32,288 & 1,239 & 46,575 & 143,655 & 3,652 & 342,648 & 19.4 \\
\hline NR6 & 11,608 & 5,746 & 62,100 & 0 & 20,829 & 8,8264 & 2,010 & 190,557 & 10.8 \\
\hline NR7 & 6,344 & 8,413 & 9,944 & 392 & 4,4481 & 86,348 & 1,409 & 157,330 & 8.9 \\
\hline $\begin{array}{l}\text { Total } \\
\text { (GJ) }\end{array}$ & 92,987 & 184,831 & 238,944 & 2,653 & 236,679 & 994,823 & 17,739 & 176,8656 & \\
\hline$(\%)$ & 5.3 & 10.5 & 13.5 & 0.2 & 13.4 & 56.2 & 1.0 & & 100.00 \\
\hline
\end{tabular}




\section{Industrial Sector}

As shown in Table 2.4, industrial sector heat and hot water consumption is provided almost exclusively by district heat, $78 \%$, and another $10 \%$ provided is by gaseous fuels in individual boilers.

\subsubsection{Industrial Process Energy}

Energy consumed for industrial processes is shown in Table 2.8 for the five major industrial sectors in Plzeñ. The machine tool industry and steel production sector account for nearly $60 \%$ of process energy followed by food processing at $28 \%$ and paper processing at $11 \%$. District heat is the major fuel type, providing $46 \%$ of industrial process energy, of which nearly three fourths is consumed in the machine tool and steel sector. Of the gaseous fuels, over half are consumed in the machine tool and steel sector and $40 \%$ are consumed in the food industry.

Table 2.8. Industrial Sector Heat Energy Consumption by Fuel Type, Equipment Type, and Subsector, 1989

\begin{tabular}{|c|c|c|c|c|c|c|}
\hline \multirow[b]{2}{*}{ Sector } & \multicolumn{3}{|c|}{ Boilers and Other Processes } & \multirow[b]{2}{*}{$\begin{array}{c}\text { District } \\
\text { Heat (GJ) } \\
\end{array}$} & \multirow[b]{2}{*}{$\begin{array}{l}\text { Total } \\
\text { (GJ) }\end{array}$} & \multirow[b]{2}{*}{$(\%)$} \\
\hline & $\begin{array}{l}\text { Fuels } \\
\text { (GJ) }\end{array}$ & $\begin{array}{c}\text { Oil } \\
\text { (GJ) }\end{array}$ & Gas (GJ) & & & \\
\hline $\begin{array}{l}\text { Machine Industry + } \\
\text { Steel }\end{array}$ & 172,800 & 0 & 856,625 & $1,326,000$ & $2,355,425$ & 58.28 \\
\hline $\begin{array}{l}\text { Production of } \\
\text { Construction } \\
\text { Materials (pre-fab } \\
\text { blocks) }\end{array}$ & 12,839 & 33,598 & 15,221 & 0 & 61,658 & 1.53 \\
\hline Paper Industry & 49,254 & 382,255 & 0 & 0 & 431,509 & 10.68 \\
\hline Agriculture & 0 & 0 & 50,098 & 0 & 50,098 & 1.24 \\
\hline $\begin{array}{l}\text { Food processing } \\
\text { (brewery) }\end{array}$ & 14,460 & 0 & 591,163 & 536,918 & $1,142,541$ & 28.27 \\
\hline Total (GJ) & 249,353 & 415,853 & $1,513,107$ & $1,862,918$ & $4,041,231$ & \\
\hline$(\%)$ & 6.17 & 10.29 & 37.44 & 46.10 & & 100.00 \\
\hline
\end{tabular}

\subsection{Scenario Assumptions}

This section develops two scenarios for energy demand growth for the buildings and industrial sectors. . High and low growth scenarios were developed based on projected economic activity and population growth from 1993 to 2003. In the high scenario, the municipality's population is projected to increase $8 \%$ from today's 171,000 to 185,000 ; and decrease by $3.5 \%$ in the low scenario to 165,000 . 
The high scenario assumes a $4 \%$ overall growth in space and water heat energy consumption for all three sectors and about $6 \%$ for the residential and non-residential buildings sectors from 1993 to 2003 . Of the forecasted $316,000 \mathrm{GJ}$ increase, the residential sector growth rate is expected to be $0.5 \%$ $(16,000 \mathrm{GJ}), 13 \%$ for the non-residential sector $(245,000 \mathrm{GJ})$, and $2 \%$ for the industrial sector $(55,000 \mathrm{GJ})$. The low scenario projects a $1 \%$ growth in space and water heat energy demand over the same period, or about $80,000 \mathrm{GJ}$. Both scenarios forecast no change in per square meter energy use from the 1989 base period for existing buildings, and new buildings are expected to use slightly less energy per square meter than the 1989 base consumption levels. 



\subsection{Buildings Sector Efficiency Assessment}

This section presents the estimated efficiency resource in the residential and non-residential buildings and the industrial sectors. Section 3.1 describes the efficiency measures considered and not considered. The technical and economic analysis approach employed to estimate the efficiency resource is described in Section 3.2. The buildings sector efficiency resource is presented in Section 3.3. Section 3.4 provides a brief discussion of the industrial sector efficiency potential.

\subsection{Efficiency Measures}

Fifty energy conservation opportunities (ECOs) were considered for evaluation for the residential and non-residential building stock in Plzeñ. Of these, 24 ECOs were determined to be applicable to more than one building group and were analyzed with respect to energy efficiency potential, cost, and availability on the Czech market. A brief description of the ECOs follows: measures considered are presented in Section 3.1.1, measures not considered are located in Section 3.1.2, and a summary of the measures considered is located in Section 3.1.3.

\subsubsection{Efficiency Measures Considered}

The 24 efficiency measures considered are presented by category of application: building envelope, domestic water heating, heating system, and ventilation and heat recovery.

\section{Building Envelope Measures}

Insulate Building Exterior Side Walls. Insulation installed on the exterior walls of the building improves the R-value, or thermal retention, of the building shell and therefore decreases the heat losses through the walls. Depending on the method used and material thickness, the R-value of the walls may be increased by 0.8 to $1.4 \mathrm{~m}^{2} \mathrm{~K} / \mathrm{W}$. Exterior insulation also results in increasing the exterior zone temperature by as much as $3^{\circ}$ to $5^{\circ} \mathrm{C}$, thus indirectly reducing overheating of the building core space when building temperatures are properly adjusted. An additional positive effect is the elimination of moisture condensation on the interior side of the walls in cold weather. Although this ECO is widely used, poor workmanship causes the results to be less than expected in many installations.

Insulate Top Floor Ceiling. The top floor ceiling in many building types is poorly insulated, which results in a substantial heat loss from the top floor, and higher space heat to compensate for this often causes overheating of the building core space. Insulating the top floor ceiling from the interior side is applicable to buildings with a flat roof, where adding insulation from the exterior side would require extensive effort to keep the insulation protected from the weather. The ceiling insulation is designed not to upset the appearance of the apartment interior and increases the R-value by 2.1 to $3.0 \mathrm{~m}^{2} \mathrm{~K} / \mathrm{W}$.

Insulate Attic. Insulating the attic is a widely used method of reducing heat losses in a building with an attic space. The insulation may be installed in many different ways, by being blown into the attic, laid on the top of the ceiling, and poured in a liquid state. Fiberglass blankets or boards, and styrofoam boards are most commonly used. Depending on the method used, the R-value can be increased by as much as $3.5 \mathrm{~m}^{2} \mathrm{~K} / \mathrm{W}$. 
Insulate Floor Above Basement. Insulating the floor above a cold basement or crawl space improves the floor R-value as well as occupant comfort, which typically results in a lower thermostat setting. Many floor covering materials with good thermal insulation properties are available. For floors with an air cavity, blown-in cellulose-based insulation is also available.

Weatherstrip Elevator Penthouse, Stairway, Doors and Windows. Reducing infiltration by sealing cracks around doors and windows in unheated spaces such as stairways will increase the temperature in such spaces, thus reducing the heat losses from the heated space to unconditioned space. Eight to ten floor apartment buildings, which are approximately 22 to 28 meters high, can have a substantial draft through the stairway due to the stack effect. Sealing cracks in the upper part of the stairway can reduce infiltration substantially. The temperature on cold days may be increased by as much as $4^{\circ} \mathrm{C}$.

Weatherstrip Windows and Doors. Sealing cracks around windows and doors is a simple way to reduce infiltration to occupied spaces and thus reduce the energy required to heat ambient air entering the heated space. Windows, especially in older apartment buildings, fit poorly, resulting in significant levels of infiltration. In order to be functional, seals have to be properly installed and maintained.

Install Revolving or Double Door in Building Vestibule. Revolving or double doors reduce infiltration of ambient air into the unconditioned lobby or entrance space of the building as people enter or leave and also provide better sealing, thus increasing the unheated space temperature. Due to the low thermal insulation of internal walls, this may have a significant effect on heat losses from the heated space. Revolving doors are especially good for high traffic entries, such as stores, banks, etc. Double doors are good for apartment buildings.

Install Triple Pane Windows. The fenestration area of the residential structures found in the Czech Republic can be a significant fraction of the building envelope area. In some buildings, such as the T-06-B 8 story high-rise, the window area is $24 \%$ of the building shell surface. The U-value, or rate of heat loss, of the windows is 2.7 to 4.2 times greater than for walls. Subsequently, the heat losses through the windows are significant. Triple pane windows with high performance glass provide improved R-value for the fenestration area and reduce heat loss through the glass. The U-value, or rate of heat loss, of a triple pane window is typically $1.6 \mathrm{~W} / \mathrm{m}^{2} \mathrm{~K}$, whereas the regularly used window has U-value of 2.6 to $2.8 \mathrm{~W} / \mathrm{m}^{2} \mathrm{~K}$. It is also assumed that new windows will provide a tighter fit resulting in lower infiltration.

Install Storm Windows. An additional layer of glass mounted in its own frame, either on the inside or outside of the existing window, improves the total R-value of the fenestration area and reduces the infiltration. Storm windows may be installed seasonally or permanently. Compared with triple pane windows, this alternative offers smaller improvements of R-value, but at a lower installed cost.

Install Heat Reflectors Behind Each Radiator or Heater. Heat reflectors deflect the radiant portion of the heat otherwise absorbed by the wall (in most cases an exterior wall) into the heated space. The wall temperature behind the radiator is lowered and the R-value of the part of the wall covered by reflector is increased, thus reducing the heat losses. This is in many cases a "do-it-yourself" inexpensive job.

Remove Draperies from Radiator. Radiators are typically located under the windows and covered by window draperies, especially during the evening and night hours. The draperies then form an air channel which forces the heated air leaving the radiator to flow closer to the window and thus create a 
local environment with higher temperatures. This increases the heat loss through the window. Removing draperies does not require any investments and will be most likely done by the occupant, providing he/she is responsible for the heating bill. An educational effort is required to implement this change.

\section{Domestic Water Heating}

Install Low-Flow Shower Heads. Low-flow shower heads available on the market can reduce the required water flow by $17 \%$ to $50 \%$ without sacrificing user comfort. These shower heads create the same "massaging" effect as high water flow models. Shower heads are easy to install and do not require plumbing changes.

Install Flow Restrictors in Faucets. Restrictors reduce the flow of water in bathroom and kitchen faucets for washing, shaving, dishwashing, etc. Installing flow-restricting orifices is simple and inexpensive and can be done by the occupant. The water consumption for the above described purposes can be reduced by up to $50 \%$.

Insulate Hot Water Pipes in Unconditioned Spaces. Hot water pipes are in most cases already insulated. However, the old insulation is typically insufficient, damaged, or otherwise not functional. Additional or new insulation lowers the hot water heat losses.

Install Hot Water Flow Meters. This ECO assumes that the occupant is responsible for the hot water bill. Hot water flow meters, installed visibly at locations of hot water use, serve not only as energy allocation devices, but also make the occupant much more aware of hot water consumption. Occupant awareness of energy use has proven to be an effective energy saver in many installations throughout Europe and the U.S. and this ECO has been shown to result in a 7\% energy reduction.

\section{Heating System}

It is important to note that the heating systems found in multi-family residential building structures are designed with main branches and risers (a sub-branch that routes the hot water to the radiators) serving rooms in several apartments. For example, corner bedrooms on all floors are served by one riser, while comparably located living rooms on all floors are served by another riser. Without costly plumbing changes, this design does not allow control of the heating by a single zone valve for each apartment. Heat metering is also difficult for the same reason. Multiple zone valves and multiple heat allocation devices have to be used.

Balance Heating System Using Existing Valves. A properly balanced heating system should supply the correct amount of heat to each conditioned space to keep the temperature in that space within comfortable limits. In many cases, heated spaces with higher heat losses, for example corner apartments, are receiving less than the required heat due to a poorly designed heating system. In order to keep the temperature within acceptable limits, the rest of the building; especially the core portion, is greatly overheated.

Manual regulating valves are normally installed on each radiator, but if not used for a prolonged period of time, they usually leak. The occupant is not willing to take that risk and would rather open a window to lower the room temperature. The fact that the occupant is not accountable for the heating bill in many cases exaggerates this problem. 
In some buildings, the system balancing can be done by using existing balancing valves installed on risers or branches of the plumbing system. It is a very effective, low cost ECO. Balancing should be done periodically.

Install Balancing Valves on Each Radiator. This improvement is applicable to the systems where balancing valves were not originally provided. Balancing valves installed on each radiator will allow more accurate distribution of the heat throughout the building. However, this measure does not provide the occupant the ability to control the room temperature.

Install Thermostatic Radiator Valves (TRVS). Installing a TRV on each radiator provides the user with the capability to control temperature within reasonable temperature fluctuations. In order to be an effective ECO, the TRVs have to be installed together with heat allocation devices and a building GJmeter for proper allocation of heating cost. TRVs alone do not provide an incentive for saving and in many cases they are left fully open all the time. Controlled room temperature (and allocating energy cost based on individual consumer use) also discourages the occupant from unnecessarily opening windows, thus significantly reducing the infiltration rate.

Install Zone Valves on Each Radiator and Install Central Thermostat with "On-Time Counter" in Each Apartment. Zone valves, installed on each radiator and controlled by a single thermostat located centrally in the apartment, provide excellent temperature control with good accuracy. Temperature in the apartment is controlled more tightly than by TRVs and operation of the thermostat is more "userfriendly." A thermostat with an electronic "On-Time counter" is a heat meter that can be used in place of cumbersome evaporative type heat allocation devices. The use of a building-level GJ-meter is also assumed with this measure.

Install Zone Valves on Each Radiator and Install Central Programmable Thermostat with TOD and "On-Time" Counter in Each Apartment. An additional feature of this ECO, as compared to the prior $\mathrm{ECO}$, is the capability to program the thermostat to maintain the room temperature based on occupancy for a one- or two-week period. Lowering the temperature during the unoccupied period can save a significant amount of energy. The use of a building-level GJ-meter is also assumed with this measure.

Install Building Energy Management System (EMS). An Energy Management System tailored for a specific building or group of buildings provides the most energy savings in this category. An apartment building consisting of 40 to 50 living units controlled by an EMS can save as much as $48 \%$ of the space heating energy. The EMS controls the energy source to provide optimal temperature of the heating media, controls the space temperatures allowing occupants to set the temperature in each zone, etc. The EMS also collects energy use information and, for billing purposes, is accessible by the utility through the phone line. The cost of such systems may be prohibitive at existing energy costs in the Czech Republic.

\section{Ventilation and Heat Recovery}

Install Heat Recovery Vent System in Basements. Typically, the basements in apartment buildings serve as storage spaces, bicycle and baby-carriage storage areas, laundry rooms, etc. The basement is vented through permanently open ventilation windows. Installation of a heat recovery unit provides fresh air to the storage spaces at $90 \%$ heat recovery efficiency (provided all cracks, openings for piping, broken windows, etc., are sealed) and may increase the basement temperature during cold days by as much as $3^{\circ} \mathrm{C}$. 
. Install Waste Water Heat Recovery Heat Exchanger. Utilizing the heat from waste water for preheating the cold water entering the hot water heater results in a sizable reduction of the heater capacity required for water heating. Apartment buildings with central water sewage pipes are the ideal candidates for such an ECO, but this method is not applicable to all building groups. Up to $25 \%$ of heat required for water heating can be saved.

Install Bath/Kitchen Vent Heat Recovery Heat Exchanger. Open ventilation ducts from kitchens and bathrooms in apartment buildings cause unnecessary infiltration. Installing air dampers which operate with the exhaust fans and installing heat recovery heat exchangers prevent unnecessary infiltration and provide controlled air return with up to $90 \%$ heat recovery.

\subsubsection{Efficiency Measures Not Considered}

A number of Energy Conservation Opportunities identified were not considered for further evaluation because they did not offer an adequate level of efficiency improvement potential; they could only be addressed through a more focused data collection effort beyond the scope of this effort; they would address only a small part of the building stock; and/or they were applicable to the energy supply side. The ECOs applicable to residential buildings that were not considered are presented in this subsection by ECO category.

\section{Building Envelope}

Insulate Roofs with No Attic Space. Installing exterior insulation on flat and tile roofs is expensive, as this essentially requires installing a new roof and ensuring that the roof is waterproof. Additional data collection would also have been required to evaluate this measure.

Add Internal Insulation in Walls. This measure is expensive to implement, affects the appearance of the interior, and imposes a considerable burden on the occupant.

Insulate Roof Panel Cavities. Adding insulation may reduce or eliminate cavity ventilation and possibly create moisture condensation inside the cavity.

Insulate Exterior Walls of Historical Buildings and Single-and Two-Family Homes. This was rejected as unacceptable for the historic buildings and too expensive for the other building groups.

Insulate Apartment Building Exterior Walls Having Windows. This was considered too expensive to do in a manner that would be acceptable from an appearance standpoint.

Insulate Internal Walls Between Heated and Unheated Spaces (Stainways). This was not considered to provide sufficient efficiency improvement and would have required additional data collection and analysis to evaluate.

Insulate Basement Perimeter Above the Ground. This was not considered to provide sufficient efficiency improvement and would have required additional data collection and analysis to evaluate.

Repair Leaking Roofs Which Cause Wet Walls and Insulation to Become Ineffective. This was not considered to be a common measure and would have required additional data collection and analysis to evaluate. 


\section{Domestic Water Heating}

Replace Electric Water Heaters with Gas or LP Gas Water Heaters. This was not considered to be a common measure and would have required additional data collection and analysis to evaluate.

Insulate Hot Water Pipes in Conditioned Space. This was not considered to be a cost-effective measure and would have required additional data collection and analysis to evaluate.

Lower Hot Water Temperatures. Domestic water temperature is maintained at $55^{\circ} \mathrm{C}$, and lowering the temperature may introduce a health hazard.

Use of Cold Water for Laundry Washing. Detergents effective in cold water are not yet available.

Install Overhead Showers to Promote Use of Showers. While showers use less water than baths, on average, bathing in a tub is common and it would require significant effort to effect a lifestyle change.

\section{Heating System}

Re-Work Building Heating System Plumbing. Re-designing and re-working the building heating system to allow a single control and energy consumption measurement point for each apartment was not considered cost-effective.

Replace or Improve Existing Gas or Coal Room Heaters. This was not considered to be a common measure and would have required additional data collection and analysis to evaluate.

Insulate Boilers and Water Heaters to Reduce Standby Losses. This would have required additional data collection and analysis to evaluate.

Switch Fuel. This supply-related measure was beyond the scope of this analysis.

Replace Circulating Pumps and Temperature and Flow Control Components with High Performance Parts. This would have required additional data collection and analysis to evaluate.

Insulate Conduits Between Boiler or Heat Exchanger and Building. This would have required additional data collection and analysis to evaluate.

Use Heat Pumps for Space and Water Heating. The Czech climate would require a ground source heat pump for efficient operation. Additional data collection and analysis would have been required to evaluate heat pump water heaters.

Use Thermal Storage. This is too expensive, and additional data collection and analysis would have been required for evaluation.

Implement Non-Conventional Energy Sources, Such as Solar, Geothermal, Waste Heat from Local Industry, etc. This was not considered to be a common measure and would have required additional data collection and analysis to evaluate. 
Improve Maintenance (Cleaning) of the Heat Sources, Such as Local Boilers, Room Heaters, etc. This would have required additional data collection and analysis to evaluate.

Install Supply Water Temperature Reset Control Systems. This would have required additional data collection and analysis to evaluate.

\section{Ventilation and Heat Recovery}

Install Indoor Air Quality Ventilation/Heat Recovery Units. High efficiency heat recovery ventilation units in each room or apartment would introduce fresh air into the space with a heat recovery rate of approximately $90 \%$. The cost of such units was not considered cost-effective.

Install Combustion Air Preheating for Local Heaters. This supply-related measure was beyond the scope of this analysis.

\subsubsection{Summary of Efficiency Measures Considered}

Table 3.1 summarizes the 24 efficiency measures considered by cost per unit of application and measure lifetime.

Table 3.1. Efficiency Measures Considered and Estimated Per Unit Cost and Lifetime

\begin{tabular}{|c|c|c|c|c|}
\hline Number & Energy Saving Option Description & Unit & Cost (Ke/Unit) & $\begin{array}{l}\text { Lifetime } \\
\text { (Years) } \\
\end{array}$ \\
\hline \multicolumn{5}{|c|}{ Building Envelope } \\
\hline 1 & Insulate Building Exterior Side Walls & $\mathrm{m}^{2}$ & $700-800$ & 30 \\
\hline 2 & Insulate Top Floor Ceiling & $\mathrm{m}^{2}$ & 700 & 30 \\
\hline 3 & Insulate Attic & $\mathrm{m}^{2}$ & 385 & 30 \\
\hline 4 & Insulate Floor Above Basement & $\mathbf{m}^{2}$ & 650 & 30 \\
\hline 5 & $\begin{array}{l}\text { Weatherstrip Elevator Penthouse, Stairway, Doors and } \\
\text { Windows }\end{array}$ & $\mathbf{m}$ & 40 & 10 \\
\hline 6 & Weatherstrip Windows and Doors & m & 30 & 10 \\
\hline 7 & Install Revolving or Double Door in Building Vestibule & unit & 24,000 & 30 \\
\hline 8 & Install Triple Pane Windows & $\mathrm{m}^{2}$ & 5,409 & 30 \\
\hline 9 & Install Storm Windows & $\mathrm{m}^{2}$ & 600 & 30 \\
\hline 10 & Install Heat Reflectors Behind Each Radiator or Heater & $\mathrm{m}^{2}$ & 148 & 5 \\
\hline 11 & Remove Draperies from Radiator & & $\mathbf{0}$ & \\
\hline
\end{tabular}


Table 3.1. (contd)

\begin{tabular}{|c|c|c|c|c|}
\hline Number & Energy Saping Option Description & Unit & Cost (Ke/Unit) & $\begin{array}{l}\text { Lifetime } \\
\text { (Years) } \\
\end{array}$ \\
\hline \multicolumn{5}{|c|}{ Domestic Water Heating } \\
\hline 12 & Install Low-Flow Shower Heads & unit & 400 & 10 \\
\hline 13 & Install Flow Restrictors in Faucets & unit & 70 & 5 \\
\hline 14 & Insulate Hot Water Pipes in Unconditioned Spaces & $\mathrm{m}$ & 158 & 15 \\
\hline 15 & Install Hot Water Flow Meters & unit & 600 & 30 \\
\hline \multicolumn{5}{|c|}{ Heating System } \\
\hline 16 & Balance Heating System Using Existing Valves & flat & 400 & 5 \\
\hline 17 & Install Balancing Valves on Each Radiator & unit & 350 & 15 \\
\hline \multirow[t]{3}{*}{18} & a. Install Thermostatic Radiator Valves (TRVs) & unit & 380 & 15 \\
\hline & b. Install Heat Allocators/Meters & unit & 67 & 1 \\
\hline & c. Install Building-Level GJ Meter & unit & 24,000 to 46,000 & 30 \\
\hline \multirow[t]{3}{*}{19} & a. Install Zone Valves on Each Radiator & unit & 330 & 15 \\
\hline & $\begin{array}{l}\text { b. Install Central Thermostats with On-Time Counter in } \\
\text { Each Flat }\end{array}$ & unit & 2300 & 15 \\
\hline & c. Install Building-Level GJ Meter & unit & 24,000 to 46,000 & 30 \\
\hline \multirow[t]{3}{*}{20} & a. Install Zone Valves on Each Radiator & unit & 330 & 15 \\
\hline & $\begin{array}{l}\text { b. Install Central Programmable Thermostats with } \\
\text { On-Time Counter in Each Flat }\end{array}$ & unit & 6120 & is \\
\hline & c. Install Building-Level GJ Meter & unit & 24,000 to 46,000 & 30 \\
\hline 21 & Install Building Energy Management System (EMS). & $\begin{array}{l}\text { unit - } \\
\text { radiator }\end{array}$ & 7,000 & 30 \\
\hline \multicolumn{5}{|c|}{ Ventilation and Heat Recovery } \\
\hline \multirow[t]{2}{*}{22} & a. Install Heat Recovery Vent System in Basements & unit & 7,600 & 10 \\
\hline & b. Weatherstrip Basement Windows and Doors & $\mathrm{m}$ & 40 & 10 \\
\hline 23 & Install Waste Water Heat Recovery Heat Exchanger & unit & 10,200 to 126,000 & 15 \\
\hline \multirow[t]{2}{*}{24} & $\begin{array}{l}\text { a. Install Bath/Kitchen Vent Heat Recovery Heat } \\
\text { Exchanger }\end{array}$ & unit & 9,050 & 10 \\
\hline & b. Install Back-Flow Damper in Kitchen/Bath Vent Duct & unit & 350 & 15 \\
\hline
\end{tabular}




\subsection{Analysis Approach}

The 24 measures were analyzed for the 11 residential building types by the six fuel and equipment types identified: on-site gas, on-site coal, boiler house gas, boiler house coal, district heat, and electricity. Measures were not analyzed for electric space heating, as this represents only $1.3 \%$ of the total heating load. Measures were considered for application to electric water heat.

A possibility not analyzed is that base space and water heat use may increase due to increases in living standards. Should base use increase, the efficiency potential will also increase by a comparable amount.

The weather data required for computation of building loads and energy saving were not available for Plzeñ, so 1989 weather data for Prague, Czech Republic, was used for the load calculations.

The technical analysis approach for developing the estimated per measure efficiency improvement for each measure category is described in Section 3.2.1. The economic analysis method is discussed in Section 3.2.2.

\subsubsection{Technical Analysis Method}

The analysis method applied to each category of efficiency measures is described in this subsection.

\section{Analyses of Building Envelope Measures}

The ASEAM3 (A Simplified Energy Analysis Method, version 3.0) computer program for simulating heat losses in buildings based on procedures recommended by the American Society for Heating, Refrigeration and Air Conditioning Engineers (ASHRAE) Fundamentals was used for the analysis. The program provides prediction of maximum heat loads, annual energy consumption, and the effect of other factors on building heat loads (occupancy, lighting, appliance usage, insulation, etc.)

Baseline and post-measure installation heat loss was calculated for each measure. The difference between the two heat loss values is the energy savings. The development of the baseline building heating loads for each building type required making several assumptions. The most important were infiltration rates, internal temperatures in different locations, and occupancy and equipment schedules. These assumptions were based on recommended values, previous experience, and information gathered by survey (number of opened windows in apartments in occupied and unoccupied periods).

In the modeling of each $\mathrm{ECO}$, only the pertinent value describing the given $\mathrm{ECO}$ was changed in the model. Insulation of walls, ceilings and floors was modeled by lower U-values; weatherstripping of windows was modeled by lowering the infiltration coefficient; installation of triple pane and storm windows was accomplished by lowering the window U-value; weatherstripping of stairway windows and doors, and installation of entrance double doors were modeled by increasing the unheated space temperature; and installation of a heat recovery unit for the bath/kitchen was accomplished by reducing the infiltration rate. 


\section{Analyses of Water Heating Measures}

Energy saving calculations for low flow shower heads and faucet flow restrictors are based on statistical information regarding the use of hot water in the Czech Republic, statistical information on hot water use by purpose (dishwashing, shower, laundry, etc.), and manufacturers' performance information. The calculation of energy savings obtainable by insulating the hot water pipes in unconditioned spaces is based on lowering heat losses through additional pipe insulation with improved $\mathrm{R}$-value or replacement of existing insulation with high performance materials. Due to the limited nature of this project, exact length and sizes of pipes could not be determined, but rather were estimated for each building group based on typical plumbing designs.

\section{Analyses of Building Heating System}

All ECOs analyzed in this category provide improved energy management in the building. Installation of temperature control devices (TRV, TS, EMS) in conjunction with installation of energy cost allocation equipment provide building occupants with an incentive to reduce energy consumption. The use of a programmable thermostat also improves the use of setback during unoccupied periods. The combination of better energy management and distribution within the building and the ability of motivated occupants to lower the energy consumption results in two effects:

- Room temperature is kept at the lowest acceptable level.

- Windows are opened only to maintain acceptable indoor air quality and not for temperature control.

The computerized calculations used for the building heating system energy saving measures were also derived from the procedures recommended by the ASHRAE Fundamentals. For each measure, both the baseline and post-measure installation heat loss were calculated. The difference between the two heat loss values is the energy use reduction. For each ECO analyzed, the temperatures and infiltration rates were estimated based on the performance of the proposed equipment and expected occupant behavior. In general, more accurate equipment and more motivated occupants will produce lower temperatures and lower infiltration rates. The temperatures were not assumed to drop below accepted comfort limits (for example, $21^{\circ} \mathrm{C}$ in living rooms and $18^{\circ} \mathrm{C}$ in bedrooms).

\section{Analyses of Ventilation and Heat Recovery Measures}

The energy saving calculations developed for the heat recovery applications were again derived from procedures recommended by the ASHRAE Fundamentals. Inputs to the calculations include properties and mass flow of media from which the waste heat is recovered and manufacturers' performance characteristics for the heat recovery equipment.

\subsubsection{Economic Analysis}

This section presents the economic analysis metrics, the economic assumptions, and the approach employed to assess the economic performance of the efficiency measures. 


\section{Analysis Metrics}

The ECOs described in the previous section were analyzed in a number of ways, with the intent of presenting a variety of what are called "analysis metrics". for measuring the attractiveness of an ECO as an investment. A number of economic metrics commonly used to evaluated measure effectiveness are present value, net present value, simple payback, and levelized energy cost. These methods are described in this section.

\section{Present Value and Net Present Value}

Present values account for the fact that a crown today is worth more than a crown tomorrow, for two principal reasons: general price inflation and the time value of money. In the face of general price inflation, the purchasing power of a crown declines over time, and since the true value of money lies in what it is capable of purchasing, inflation causes its value to decline. The time value of money refers to the fact that even in the absence of general price inflation, money received sooner is preferred to money received later.

It is this preference for consuming sooner rather than later that leads to the existence of positive rates of interest, even in the absence of price level inflation. Individuals and firms are willing to pay a premium to obtain goods and services sooner rather than later: the premium they are willing to pay is the "real rate of interest." The market rate of interest, or the "nominal" rate, is the real rate plus the rate of inflation (this is a slight simplification). As an example, $100 \mathrm{Kc}$ received two years from today is worth only $82.64 \mathrm{Kc}$ today, assuming a ten percent interest rate. Conversely, $82.64 \mathrm{Kc}$ invested today at ten percent per annum yields $100 \mathrm{Kc}$ two years later.

The costs and the benefits of an efficiency investment occur at different periods of time, which must be accounted for in the analysis. The metric selected for this is net present value to calculate the present value of all of the costs associated with an ECO, less the present value of all of the benefits of the ECO. The NPV is a measure of the total value of the energy efficiency investment and is used to define the cost-effectiveness of an ECO: a negative NPV means that the costs of an ECO outweigh its benefits, while a positive NPV means that the benefits are greater than the costs. The higher the NPV, the better.

\section{Simple Payback}

The most basic analysis metric used is the simple payback period, which, in its simplest form is calculated by dividing the installed cost of the ECO by the value of the annual energy savings. "The simple payback period is then the number of years required for the savings resulting from an investment in energy efficiency to offset the cost of the investment: thus, the lower the payback period, the more attractive the investment.

In many analysis situations, this metric is too simplistic to be of much use. ECOs with future costs may be overvalued if these costs are not accounted for. Escalating fuel prices will undervalue the ECO. Simple payback does not enable ready comparison for measures having different useful lifetimes. This method also does not account for the time value of money and may not be readily comparable with other investments using more sophisticated measures of value. 


\section{Levelized Energy Cost}

A slightly more complex metric is the levelized energy cost (LEC), also called the cost of conserved energy, expressed in Kc/GJ. The LEC is the total cost of an ECO over the measure life, converted to an annual value (the installed cost is "levelized," from a lump sum into a series of equal annual payments), divided by the annual energy savings in GJ. The LEC is used to compare the cost of the energy resource obtained through conservation with the cost of energy from other sources, such as purchasing energy from the district heat system, or purchasing coal for use in on-site boilers. The LEC allows the calculation of a supply curve for energy efficiency. The supply curve shows the total annual energy conservation resource available at any given cost per unit of energy conserved.

Using the supply curve, it is possible to determine the conservation resource available for less than or equal to the cost of competing resources, such as coal, district heat systems, or natural gas.

\section{Economic Assumptions}

Two types of economic analysis methods typically used are nominal and real. A nominal analysis is performed using current money values, reflecting the effects of inflation. The value of energy savings in 1993 is expressed in money with 1993 purchasing power, the value of energy savings in 1994 is expressed in money with 1994 purchasing power, and so on. The value of the energy savings continues to increase because of inflation in the general level of prices. A real analysis expresses all money values in constant terms by removing the effects of inflation. In the case of this analysis, all values are expressed in 1993 currency values.

The implications of using a real analysis are the need to calculate a real discount rate, which is basically the interest rate after the effects of inflation have been removed. For the purposes of this analysis, a simplification was used, whereby the real discount rate is calculated as the nominal interest rate minus the expected rate of inflation.

In driving the economic analysis, three sets of assumptions were employed for evaluating the costeffectiveness of the efficiency measures by the economic metrics. These consist of base economic assumptions and three fuel price levels.

\section{Base Assumptions}

The base economic assumptions underlying the analysis are shown in Table 3.2.

Table 3.2. Base Economic Assumptions for Analysis of Efficiency Measures

\begin{tabular}{||l|l|}
\hline Nominal Discount Rate: & $14.0 \%$ \\
\hline Expected Inflation: & $12.0 \%$ \\
\hline Real Discount Rate: & $2.0 \%$ \\
\hline Analysis Period: & 30 years \\
\hline
\end{tabular}




\section{Alternate Fuel Prices}

Energy prices are currently subject to some form of regulation and/or subsidy, both of which will be modified in the near future. In order to investigate the impact of likely changes in near-term energy prices on the energy efficiency resource, two fuel price scenarios were developed in conjunction with staff from the City, TEZA and ZCE. The prices for 1993 and the low and high scenarios are shown in Table 3.3.

Table 3.3. Fuel Price Levels Used to Drive Analysis of Efficiency Rẹsource by Fuel and Equipment Type

\begin{tabular}{||l|r|r|r|r|r|}
\hline \multicolumn{1}{|c|}{ Fuel } & $\begin{array}{c}\text { Current } \\
\text { Price } \\
\text { (Kc/GJ) }\end{array}$ & $\begin{array}{c}\text { Low Price } \\
\text { (Kc/GJ) }\end{array}$ & $\begin{array}{c}\text { High Price } \\
\text { (Kc/GJ) }\end{array}$ & $\begin{array}{c}\text { Low } \\
\text { Scenario }\end{array}$ & $\begin{array}{c}\text { High } \\
\text { Scenario }\end{array}$ \\
\hline \hline On-Site Gas & 67.50 & 100.00 & 270.00 & $48.1 \%$ & $300.0 \%$ \\
\hline On-Site Coal & 54.80 & 80.00 & 150.00 & $46.0 \%$ & $173.7 \%$ \\
\hline Electricity & 94.10 & 200.00 & 350.00 & $112.5 \%$ & $271.9 \%$ \\
\hline Boiler House Gas & 97.40 & 120.00 & 160.00 & $23.2 \%$ & $64.3 \%$ \\
\hline Boiler House Coal & 31.45 & 50.00 & 100.00 & $59.0 \%$ & $218.0 \%$ \\
\hline District Heat & 136.40 & 200.00 & 350.00 & $46.6 \%$ & $156.6 \%$ \\
\hline
\end{tabular}

The low price scenario corresponds to removal of subsidies and the high price scenario roughly corresponds to West European absolute and relative fuel prices. In both scenarios, the price increases are assumed to happen instantaneously and to increase at the same rate as general inflation, thus experiencing no change in real fuel prices.

\subsection{Buildings Sector Efficiency Assessment Results}

This section provides the energy and economic assessment of the 24 buildings sector efficiency measures considered for the analysis. The method employed to assess the efficiency potential consisted of four steps. The first was to screen the individual measures by NPV-measures having a positive NPV were retained for additional analysis. The second was to combine the measures to identify interactive effects in order to avoid double counting the efficiency potential and to deselect measures that reduced the NPV of selected bundles for individual building types. Third, the measure bundles and applicable individual measures were then evaluated for each residential building type to estimate residential sector efficiency potential. Fourth, the residential sector analysis results were extended to the non-residential buildings sector. 
The following group of seven measures having an interactive effect were selected for application:

- Insulate building exterior side walls

- Weatherstrip elevator penthouse, stairway, doors and windows

- Weatherstrip windows and doors

- Install revolving or double door in vestibule

- Install storm windows

- Install zone valves on each radiator and install central thermostats with 'on-time counter' in each apartment

- Install heat recovery vent system in basements.

Depending upon the building type, a subset of these items was selected based upon their combined performance.

The following seven measures which did not exhibit interactive effects were also selected for application depending on their performance:

- Install heat reflectors behind each radiator or heater

- Remove draperies from radiator

- Install low-flow shower heads

- Install flow restrictors on faucets

- Insulate hot water pipes in unconditioned spaces

- Install hot water flow meters

- Install waste water heat recovery heat exchanger.

\subsubsection{Baseline Efficiency Assessment}

This section first presents the efficiency assessment using the base economic assumptions and current fuel prices for the residential and non-residential buildings sectors.

\section{Residential Sector Baseline Efficiency}

Table 3.4 provides the cost-effective space and water heat efficiency resource by residential sector building, fuel and equipment type for 1993 using the base economic assumptions and fuel prices. 
Table 3.4. Residential Sector Cost-Effective Space and Water Heat Efficiency Resource by Building, Fuel and Equipment Type Using Base Assumptions and Fuel Prices, 1993

\begin{tabular}{|c|c|c|c|c|c|c|c|}
\hline \multirow[b]{2}{*}{$\begin{array}{c}\text { Building } \\
\text { Group }\end{array}$} & \multirow[b]{2}{*}{ Fuel } & \multirow[b]{2}{*}{$\begin{array}{l}\text { Baseline } \\
\text { Use (GJ) } \\
\end{array}$} & \multirow[b]{2}{*}{$\begin{array}{c}\text { Percent } \\
\text { of Total } \\
\text { Use } \\
\end{array}$} & \multicolumn{3}{|c|}{ Cost- Effective Savings } & \multirow[b]{2}{*}{$\begin{array}{c}\text { Levelized } \\
\text { Energy Cost } \\
\text { (Kc/GJ) } \\
\end{array}$} \\
\hline & & & & $\begin{array}{c}\text { Potential } \\
\text { (GJ) } \\
\end{array}$ & $\begin{array}{c}\begin{array}{c}\text { Percent } \\
\text { of Use }\end{array} \\
\end{array}$ & $\begin{array}{l}\text { Percent } \\
\text { of Total } \\
\text { Savings } \\
\end{array}$ & \\
\hline 1 & On-Site Gas & 11,250 & 0.37 & 961 & 9 & 0.12 & 18 \\
\hline 1 & On-Site Coal & 16,157 & 0.54 & 1,385 & 9 & 0.17 & 15 \\
\hline 1 & Electricity & 2,384 & 0.08 & 316 & 13 & 0.04 & 48 \\
\hline 1 & Boiler House Gas & 0 & 0.00 & 0 & - & 0.00 & - \\
\hline 1 & Boiler House Coal & 0 & 0.00 & 0 & - & 0.00 & - \\
\hline 1 & District & 0 & 0.00 & 0 & - & 0.00 & - \\
\hline 1 & Total & 29,791 & 0.99 & 2,662 & 9 & 0.33 & 20 \\
\hline 2 & On-Site Gas & 79,440 & 2.63 & 11,164 & 14 & 1.40 & 40 \\
\hline 2 & On-Site Coal & 41,623 & 1.38 & 6,736 & 16 & 0.85 & 40 \\
\hline 2 & Electricity & 6.200 & 0.21 & 0 & - & 0.00 & - \\
\hline 2 & Boiler House Gas & 23,179 & 0.77 & 2,851 & 12 & 0.36 & 40 \\
\hline 2 & Boiler House Coal & 5,257 & 0.17 & 0 & - & 0.00 & - \\
\hline 2 & District & 9,309 & 0.31 & 1,345 & 14 & 0.17 & 52 \\
\hline 2 & Total & 165,008 & 5.47 & 22,096 & 13 & 2.77 & 41 \\
\hline 3 & On-Site Gas & 151,766 & 5.03 & 45,452 & 30 & 5.70 & 44 \\
\hline 3 & On-Site Coal & 19,445 & 0.64 & 6,287 & 32 & 0.79 & 43 \\
\hline 3 & Electricity & 2,861 & 0.09 & 586 & 20 & 0.07 & 48 \\
\hline 3 & Boiler House Gas & 20,096 & 0.67 & 988 & 5 & 0.12 & 48 \\
\hline 3 & Boiler House Coal & 66,871 & 2.22 & 0 & - & 0.00 & - \\
\hline 3 & District & 89,971 & 2.98 & 26,741 & 30 & 3.36 & 95 \\
\hline 3 & Total & 351,010 & 11.64 & 80,054 & 23. & 10.05 & 61 \\
\hline 4 & On-Site Gas & 64,777 & 2.15 & 3,967 & 6 & 0.50 & 12 \\
\hline 4 & On-Site Coal & 15,445 & 0.51 & 76 & 0 & 0.01 & 0 \\
\hline$\cdot 4$ & Electricity & 2,385 & 0.08 & 484 & 20 & 0.06 & 13 \\
\hline 4 & Boiler House Gas & 1,605 & 0.05 & 105 & 7 & 0.01 & 29 \\
\hline
\end{tabular}


Table 3.4. (contd)

\begin{tabular}{|c|c|c|c|c|c|c|c|}
\hline \multirow[b]{2}{*}{$\begin{array}{c}\text { Building } \\
\text { Group }\end{array}$} & \multirow[b]{2}{*}{ Fuel } & \multirow[b]{2}{*}{$\begin{array}{l}\text { Baseline } \\
\text { Use (GJ) } \\
\end{array}$} & \multirow[b]{2}{*}{$\begin{array}{c}\text { Percent } \\
\text { of Total } \\
\text { Use } \\
\end{array}$} & \multicolumn{3}{|c|}{ Cost- Effective Savings } & \multirow[b]{2}{*}{$\begin{array}{c}\text { Levelized } \\
\text { Energy Cost } \\
(\mathbf{K c} / \mathbf{G J}) \\
\end{array}$} \\
\hline & & & & $\begin{array}{c}\begin{array}{c}\text { Potential } \\
\text { (GJ) }\end{array} \\
\end{array}$ & $\begin{array}{c}\text { Percent } \\
\text { of Use }\end{array}$ & $\begin{array}{l}\text { Percent } \\
\text { of Total } \\
\text { Savings } \\
\end{array}$ & \\
\hline 4 & Boiler House Coal & 0 & 0.00 & 0 & - & 0.00 & - \\
\hline 4 & District & 0 & 0.00 & 0 & - & 0.00 & - \\
\hline 4 & Total & 84,212 & 2.79 & 4,632 & 6 & 0.58 & 13 \\
\hline 5 & On-Site Gas & 118,157 & 3.92 & 455 & 0 & 0.06 & 0 \\
\hline 5 & On-Site Coal & 129,739 & 4.30 & 633 & 0 & 0.08 & 0 \\
\hline 5 & Electricity & 19,553 & 0.65 & 2,626 & 13 & 0.33 & 75 \\
\hline 5 & Boiler House Gas & 638 & 0.02 & 23 & 4 & 0.00 & 68 \\
\hline 5 & Boiler House Coal & 0 & 0.00 & 0 & - & 0.00 & - \\
\hline 5 & District & 144 & 0.00 & 27 & 18 & 0.00 & 107 \\
\hline 5 & Total & 268,231 & 8.90 & 3,763 & 1 & 0.47 & 53 \\
\hline 6 & On-Site Gas & 87,512 & 2.90 & 2,915 & 3 & 0.37 & 35 \\
\hline 6 & On-Site Coal & 86,493 & 2.87 & 621 & 1 & 0.08 & 0 \\
\hline 6 & Electricity & 12,876 & 0.43 & 1,709 & 13 & 0.21 & 43 \\
\hline 6 & Boiler House Gas & 1 & 0.00 & 0 & - & 0.00 & - \\
\hline 6 & Boiler House Coal & 0 & 0.00 & 0 & - & 0.00 & $-\cdots$ \\
\hline 6 & District & 359 & 0.01 & 16 & 5 & 0.00 & 59 \\
\hline 6 & Total & 187,241 & 6.21 & 5,262 & 3 & 0.66 & 34 \\
\hline 7 & On-Site Gas & 94,814 & 3.14 & 6,819 & 7 & 0.86 & 38 \\
\hline 7 & On-Site Coal & 9,267 & 0.31 & 225 & 2 & 0.03 & 6 \\
\hline 7 & Electricity & 1,431 & 0.05 & 290 & 20 & 0.04 & 47 \\
\hline 7 & Boiler House Gas & 30,362 & 1.01 & 11,091 & 37 & 1.39 & 72 \\
\hline 7 & Boiler House Coal & 7,740 & 0.26 & 143 & 2 & 0.02 & 12 \\
\hline 7 & District & 66,285 & 2.20 & 24,492 & 37 & 3.07 & 72 \\
\hline 7 & Total & 209,899 & 6.96 & 43,061 & 21 & 5.40 & 66 \\
\hline 8 & On-Site Gas & 0 & 0.00 & 0 & $\cdots$ & 0.00 & - \\
\hline 8 & On-Site Coal & 0 & 0.00 & 0 & - & 0.00 & - \\
\hline 8 & Electricity & 0 & 0.00 & 0 & - & 0.00 & -- \\
\hline
\end{tabular}


Table 3.4. (contd)

\begin{tabular}{|c|c|c|c|c|c|c|c|}
\hline \multirow[b]{2}{*}{$\begin{array}{l}\text { Building } \\
\text { Group }\end{array}$} & \multirow[b]{2}{*}{ Fuel } & \multirow[b]{2}{*}{$\begin{array}{l}\text { Baseline } \\
\text { Use (GJ) } \\
\end{array}$} & \multirow[b]{2}{*}{$\begin{array}{c}\text { Percent } \\
\text { of Total } \\
\text { Use } \\
\end{array}$} & \multicolumn{3}{|c|}{ Cost- Effective Savings } & \multirow[b]{2}{*}{$\begin{array}{c}\text { Levelized } \\
\text { Energy Cost } \\
\text { (Kc/GJ) }\end{array}$} \\
\hline & & & & $\begin{array}{c}\text { Potential } \\
\text { (GJ) }\end{array}$ & $\begin{array}{c}\text { Percent } \\
\text { of Use }\end{array}$ & $\begin{array}{l}\text { Percent } \\
\text { of Total } \\
\text { Savings }\end{array}$ & \\
\hline 8 & Boiler House Gàs & 0 & 0.00 & 0 & - & 0.00 & - \\
\hline 8 & Boiler House Coal & 0 & 0.00 & 0 & - & 0.00 & - \\
\hline $8:$ & District & 587,391 & 19.48 & 226,318 & 39 & 28.40 & 104 \\
\hline 8 & Total & 587,391 & 19.48 & 226,318 & 39 & 28.40 & 104 \\
\hline 9 & On-Site Gas & 0 & 0.00 & 0 & - & 0.00 & - \\
\hline 9 & On-Site Coal & 0 & 0.00 & 0 & - & 0.00 & $\ldots$ \\
\hline 9 & Electricity & 0 & 0.00 & 0 & - & 0.00 & - \\
\hline 9 & Boiler House Gas & 0 & 0.00 & 0 & - & 0.00 & - \\
\hline 9 & Boiler House Coal & 0 & 0.00 & 0 & - & 0.00 & - \\
\hline 9 & District & 301,528 & 10.00 & 122,754 & 41 & 15.41 & 92 \\
\hline 9 & Total & 301,528 & 10.00 & 122,754 & 41 & 15.41 & 92 \\
\hline 10 & On-Site Gas & 0 & 0.00 & 0 & $\cdots$ & 0.00 & - \\
\hline 10 & On-Site Coal & 0 & 0.00 & 0 & - & 0.00 & - \\
\hline 10 & Electricity & 0 & 0.00 & 0 & - & 0.00 & - \\
\hline 10 & Boiler House Gas & 1,418 & 0.05 & 486 & 34 & 0.06 & 88 \\
\hline 10 & Boiler House Coal & 0 & 0.00 & 0 & - & 0.00 & - \\
\hline 10 & District & 113,862 & 3.78 & 41,395 & 36 & 5.20 & 46 \\
\hline 10 & Total & 115,280 & 3.82 & 41,881 & 36 & 5.26 & 46 \\
\hline 11 & On-Site Gas & 26,195 & 0.87 & 977 & 4 & 0.12 & 53 \\
\hline 11 & On-Site Coal & 0 & 0.00 & 0 & - & 0.00 & - \\
\hline 11 & Electricity & 0 & 0.00 & 0 & - & 0.00 & - \\
\hline 11 & Boiler House Gas & 31,390 & 1.04 & 14,043 & 45 & 1.76 & 55 \\
\hline 11 & Boiler House Coal & 153,409 & 5.09 & 333 & 0 & 0.04 & 0 \\
\hline 11 & District & 504,617 & 16.74 & 228,945 & 45 & 28.73 & 54 \\
\hline 11 & Total & 715,611 & 23.73 & 244,299 & 34 & 30.66 & 54 \\
\hline All & On-Site Gas & 633,911 & 21.02 & 72,711 & 11 & 9.13 & 40 \\
\hline All & On-Site Coal & 318,169 & 10.55 & 15,962 & 5 & 2.00 & 35 \\
\hline
\end{tabular}


Table 3.4. (contd)

\begin{tabular}{|c|c|c|c|c|c|c|c|}
\hline \multirow[b]{2}{*}{$\begin{array}{c}\text { Building } \\
\text { Group } \\
\end{array}$} & \multirow[b]{2}{*}{ Fuel } & \multirow[b]{2}{*}{$\begin{array}{l}\text { Baseline } \\
\text { Use (GJ) }\end{array}$} & \multirow[b]{2}{*}{$\begin{array}{c}\text { Percent } \\
\text { of Total } \\
\text { Use } \\
\end{array}$} & \multicolumn{3}{|c|}{ Cost- Effective Savings } & \multirow[b]{2}{*}{$\begin{array}{c}\text { Levelized } \\
\text { Energy Cost } \\
\text { (Kc/GJ) } \\
\end{array}$} \\
\hline & & & & $\begin{array}{c}\text { Potential } \\
\text { (GJ) } \\
\end{array}$ & $\begin{array}{c}\text { Percent } \\
\text { of Use }\end{array}$ & $\begin{array}{l}\text { Percent } \\
\text { of Total } \\
\text { Savings } \\
\end{array}$ & \\
\hline All & Electricity & 47,690 & 1.58 & 6,012 & 13 & 0.75 & 55 \\
\hline All & Boiler House Gas & 108,689 & 3.60 & 29,586 & 27 & 3.71 & 60 \\
\hline All & Boiler House Coal & 233,277 & 7.74 & 476 & 0 & 0.06 & 4 \\
\hline All & District & $1,673,466$ & 55.50 & 672,034 & 40 & 84.34 & 80 \\
\hline All & Total & $3,015,202$ & 100.00 & 796,781 & 26 & 100.00 & 74 \\
\hline
\end{tabular}

The $797,000 \mathrm{GJ}$ of cost-effective savings represents a $26 \%$ reduction in current residential sector energy consumption. This ranges from decreases of $1 \%$ to $23 \%$ of current use for building groups 1 through 7 , and $34 \%$ to $41 \%$ of current use for building groups 8 through 11 . Residential district heating energy use can be cost-effectively reduced by $40 \%$, which represents over $84 \%$ of all of the cost-effective efficiency potential. Residential natural gas consumption can be reduced by $38 \%$, accounting for $13 \%$ of the efficiency potential, and coal consumption can be reduced by $5 \%$, which represents about $2 \%$ of the efficiency potential: Residential electricity use can be cost-effectively reduced by $13 \%$, although this represents less than $1 \%$ of total cost-effective efficiency potential.

Table 3.5 provides an economic analysis of the residential sector efficiency resource presented in Table 3.4 .

The residential sector cost-effective efficiency resource of 797,000 GJ annually is expected to cost about 1,167 million $\mathrm{Kc}$ and have a net present value of 937 million $\mathrm{Kc}$. The cost of conserved energy .(the annualized cost divided by the annual energy use reduction) works out to an average of $74 \mathrm{Kc} / \mathrm{GJ}$ for all fuels. While high rise apartment buildings (building types 8-11) supplied by district heat account for about $50 \%$ of residential sector heat and hot water energy consumption, they account for nearly $80 \%$ of the cost-effective efficiency resource. This $79 \mathrm{Kc} / \mathrm{GJ}$ estimated cost of this resource appears to be very cost-effective when compared to the current price of $136 \mathrm{Kc} / \mathrm{GJ}$ for district heat.

In comparison to the cost-effective resource above, if all 24 measures were implemented regardless of cost effectiveness, the efficiency resource is estimated to be 1.1 million GJ at a cost of 1.8 billion $\mathrm{Kc}$ and annual savings of 145 million Kc, providing for a per GJ cost of $95 \mathrm{Kc}$. In this case, the net present value decreases to 350 million $\mathrm{Kc}$ due to the increased cost of the measures.

\section{Non-Residential Sector Baseline Efficiency}

The non-residential cost-effective efficiency resource was estimated by applying the percentage of cost-effective energy efficiency in residential buildings to the space and water heating energy use in the non-residential buildings sector. The estimated non-residential efficiency resource for 1993 using the base economic values and fuel prices is shown in Table 3.6. 
Table 3.5. Economic Analysis Results of Residential Sector Cost-Effective Energy Efficiency Resource for 1993 Baseline

\begin{tabular}{|c|c|c|}
\hline Scenario & $\begin{array}{c}\text { All Fuels, All } \\
\text { Building Groups }\end{array}$ & $\begin{array}{c}\text { District Heating, Building } \\
\text { Groups 8-11 } \\
\end{array}$ \\
\hline Fuel Price Scenario: & 1993 & 1993 \\
\hline Economic Assumptions: & Default & Default \\
\hline $\begin{array}{l}\text { Annual Ėnergy Use } \\
\text { Reduction (GJ): }\end{array}$ & 796,781 & 619,412 \\
\hline $\begin{array}{l}\text { Value of Annual } \\
\text { Savings (Million } 1992 \mathrm{Kc} \text { ): }\end{array}$ & 101 & $\begin{array}{r}84 \\
84 \% \\
\end{array}$ \\
\hline $\begin{array}{l}\text { Present Value of Energy } \\
\text { Savings (Million } 1992 \mathrm{Kc} \text { ): }\end{array}$ & 2,260 & $\begin{array}{r}1,892 \\
84 \%\end{array}$ \\
\hline $\begin{array}{l}\text { Total Installed } \\
\text { Cost (Million } 1992 \mathrm{Kc} \text { ): }\end{array}$ & 1,167 & $\begin{array}{r}980 \\
84 \%\end{array}$ \\
\hline $\begin{array}{l}\text { PV of Installed } \\
\text { Cost (Million } 1992 \mathrm{Kc} \text { ): }\end{array}$ & 1,323 & $\begin{array}{r}1,100 \\
83 \%\end{array}$ \\
\hline $\begin{array}{l}\text { Simple Payback } \\
\text { Period (Years): }\end{array}$ & 12 & 12 \\
\hline $\begin{array}{l}\text { Net Present } \\
\text { Value (Million } 1992 \mathrm{Kc} \text { ): }\end{array}$ & 937 & $\begin{array}{r}792 \\
85 \% \\
\end{array}$ \\
\hline $\begin{array}{l}\text { Annualized Cost } \\
\text { (Million } 1992 \mathrm{Kc} / \mathrm{Yr} \text { ): }\end{array}$ & 69 & $\begin{array}{r}49 \\
83 \% \\
\end{array}$ \\
\hline $\begin{array}{l}\text { Cost of Conserved } \\
\text { Energy }(1992 \mathrm{Kc} / \mathrm{GJ}) \text { : }\end{array}$ & 74 & 79 \\
\hline
\end{tabular}

Table 3.6. Estimated Non-Residential Space and Water Heat Efficiency Potential by Fuel and Heating System Type, 1993

\begin{tabular}{||c|c|c|c|r|r|r||}
\hline \multirow{2}{*}{ Gas } & \multicolumn{2}{|c|}{ On-Site } & \multicolumn{2}{c|}{ Boiler House } & \multirow{2}{*}{} & \multirow{2}{*}{ Total } \\
\cline { 2 - 5 } & Coal & Electric & Gas & \multicolumn{1}{c|}{ Coal } & District Heat & \multicolumn{1}{c|}{ Ton } \\
\hline \hline 21,201 & 4,665 & 2,236 & 64,426 & 488 & 399,503 & 492,519 \\
\hline
\end{tabular}

Keeping in mind that this is a very rough estimate, the cost-effective efficiency potential in the nonresidential amounts to nearly $493,000 \mathrm{GJ}$ annually. This represents about a $28 \%$ reduction in nonresidential energy consumption; and over $80 \%$ of this resource is supplied by district heat. 


\subsubsection{Fuel Price Sensitivities}

This section provides the projected efficiency resource for the two fuel price scenarios by the residential and non-residential sectors. These results show the levels of efficiency resource available in the base period using the current fuel prices and the low- and high-price scenarios.

The effect of the increased fuel prices is to increase the NPV of the measures, thus making more measures cost-effective and increasing the magnitude of the efficiency resource. So, the efficiency resource is made up of all the prior ECOs plus, additional measures that become cost-effective with the higher fuel prices.

The levelized energy cost of the individual measures remains unchanged from the baseline analysis, as this value is simply the annualized installed ECO cost divided by the annual energy efficiency. But, the aggregate levelized energy cost does change because more ECOs are included in the calculation.

\section{Residential Buildings}

Table 3.7 provides the aggregate efficiency resource and economic analysis for the residential buildings sector. The high-rise apartment buildings (building types 8-11) are shown separately as they represent the majority of the efficiency resource.

Table 3.7. Residential Sector Efficiency Resource for Base and Alternate Fuel Price Scenarios, 1993

\begin{tabular}{|c|c|c|c|c|c|c|}
\hline \multirow{2}{*}{\begin{tabular}{|l} 
Scenario \\
Fuel Price Scenario:
\end{tabular}} & \multicolumn{3}{|c|}{ All Residential Buildings } & \multicolumn{3}{|c|}{$\begin{array}{l}\text { District Heat Serving Building } \\
\text { Groups 8-11 }\end{array}$} \\
\hline & 1993 & Low & High & 1993 & Low & High \\
\hline Economic Assumptions: & Default & Default & Default & Default & Default & Default \\
\hline Annual Energy Use Education (GJ): & 796,781 & 847,354 & $1,005,844$ & $\begin{array}{l}619,412 \\
78 \%\end{array}$ & $\begin{array}{c}625,727 \\
74 \%\end{array}$ & $\begin{array}{l}625,727 \\
62 \%\end{array}$ \\
\hline Value of Annual Savings (Million 1992 Kc): & 101 & 153 & 304 & $\begin{array}{r}84 \\
84 \%\end{array}$ & $\begin{array}{r}125 \\
82 \%\end{array}$ & $\begin{array}{r}219 \\
72 \%\end{array}$ \\
\hline $\begin{array}{l}\text { Present Value of Energy Savings } \\
\text { (Million } 1992 \mathrm{Kc} \text { ): }\end{array}$ & 2,260 & 3,433 & 6,800 & $\begin{array}{c}1,892 \\
84 \%\end{array}$ & $\begin{array}{r}2,803 \\
82 \%\end{array}$ & $\begin{array}{c}4,905 \\
72 \%\end{array}$ \\
\hline Total Installed Cost (Million $1992 \mathrm{Kc}$ ): & 1,167 & 1,234 & 1,509 & $\begin{array}{r}980 \\
84 \%\end{array}$ & $\begin{array}{r}987 \\
80 \%\end{array}$ & $\begin{array}{r}987 \\
65 \%\end{array}$ \\
\hline PV of Installed Cost (Million $1992 \mathrm{Kc}$ ): & 1,323 & 1,429 & 1,773 & $\begin{array}{l}1,100 \\
83 \%\end{array}$ & $\begin{array}{r}1,125 \\
79 \%\end{array}$ & $\begin{array}{l}1,125 \\
63 \%\end{array}$ \\
\hline Simple Payback Period (Years): & 12 & 8 & .5 & 12 & 8 & 5 \\
\hline Net Present Value (Million $1992 \mathrm{Kc}$ ): & 937 & 2,004 & 5,027 & $\begin{array}{r}792 \\
85 \%\end{array}$ & $\begin{array}{r}1,678 \\
84 \%\end{array}$ & $\begin{array}{c}3,780 \\
75 \%\end{array}$ \\
\hline Annualized Cost (Million $1992 \mathrm{Kc} / \mathrm{Yr}$ ): & 59 & 64 & 79 & $\begin{array}{r}49 \\
83 \%\end{array}$ & $\begin{array}{r}50 \\
79 \%\end{array}$ & $\begin{array}{r}50 \\
63 \%\end{array}$ \\
\hline Cost of Conserved Energy $(1992 \mathrm{Kc} / \mathrm{GJ})$ : & 74 & 75 & 79 & 79 & 80 & 80 \\
\hline
\end{tabular}


For the residential buildings, the fuel prices need to increase significantly to provide modest increases in the available efficiency resource. The low price scenario results in only a $6 \%$ increase in the cost-effective energy efficiency resource, although the value of these savings increases by over $50 \%$. The high price scenario results in a $26 \%$ increase in the cost-effective resource and a $200 \%$ increase in the annual value of these savings. The net present value of the energy efficiency projects rises by nearly $110 \%$ for the low price scenario and by over $430 \%$ for the high price scenario.

Under the alternate price scenarios, the bulk of the energy savings is still found in building groups 8 through 11 served by the district heat system, but they represent a smaller fraction than under the base scenario, decreasing to $74 \%$ and $62 \%$ of the residential sector efficiency for the low and high price scenarios, respectively. This is because more of the non-district-heat-related ECOs in the other 7 building types become cost-effective at the higher fuel prices.

Table 3.8 provides the cost-effective efficiency resource by fuel price scenario and fuel and heating equipment type. This shows the level of resource increasing from $26 \%$ of baseline energy use to $33 \%$ in the high fuel price scenario. Efficiency potential for the district heat, boiler house gas, and electricity fuel types are the least sensitive to fuel price increases. Efficiency potential in the on-site gas category shows sensitivity to both price levels, and the potential in the on-site coal and boiler house coal is very sensitive to the high price scenario.

\section{Non-Residential Buildings}

The non-residential sector efficiency resource by fuel price scenario and fuel and equipment type is shown in Table 3.9. This was estimated by applying the residential sector percentages to non-residential consumption.

Table 3.8. Residential Sector Cost-Effective Efficiency Resource by Fuel Price Scenario and Fuel and Heating Equipment Type

\begin{tabular}{|c|c|c|c|c|c|c|c|}
\hline \multirow[b]{2}{*}{ Scenario } & \multicolumn{3}{|c|}{ On-Site } & \multicolumn{2}{|c|}{ Boiler House } & \multirow[b]{2}{*}{ District Heat } & \multirow[b]{2}{*}{ Total } \\
\hline & Gas & Coal & Electric & Gas & Coal & & \\
\hline \multicolumn{8}{|c|}{ Baseline Energy Use (GJ) } \\
\hline Residential & 633.912 & 318,169 & 47,690 & 108,690 & 233,275 & $1,673,465$ & $3,015,201$ \\
\hline \multicolumn{8}{|c|}{ Efficiency Resource (GJ) } \\
\hline 1993 Prices & 72,712 & 15.962 & 6,012 & 29,586 & 476 & 672,033 & 796,780 \\
\hline Low Prices & 98,478 & 23.173 & 7,306 & 34,922 & 4,982 & 678,493 & 847,353 \\
\hline High Prices & 157,962 & 50,853 & 7,344 & 35,711 & 75,390 & 678,585 & $1,005,844$ \\
\hline \multicolumn{8}{|c|}{ Efficiency Resource (\% of Use) } \\
\hline 1993 Prices & $11 \%$ & $5 \%$ & $13 \%$ & $27 \%$ & $0 \%$ & $40 \%$ & $26 \%$ \\
\hline Low Prices & $16 \%$ & $7 \%$ & $15 \%$ & $32 \%$ & $2 \%$ & $41 \%$ & $28 \%$ \\
\hline High Prices & $25 \%$ & $16 \%$ & $15 \%$ & $33 \%$ & $32 \%$ & $41 \%$ & $33 \%$ \\
\hline
\end{tabular}


Table 3.9. Non-Residential Sector Cost-Effective Efficiency Resource by Fuel Price Scenario and Fuel and Heating Equipment Type

\begin{tabular}{|c|c|c|c|c|c|c|c|}
\hline \multirow[b]{2}{*}{ Sector } & \multicolumn{3}{|c|}{ On-Site } & \multicolumn{2}{|c|}{ Boiler House } & \multirow[b]{2}{*}{ District Heat } & \multirow[b]{2}{*}{ Total } \\
\hline & Gas & Coal & Electric & Gas & Coal & & \\
\hline \multicolumn{8}{|c|}{ Baseline Energy Use (GJ) } \\
\hline Non-Residential & 184,831 & 92,987 & 17,739 & 236,679 & 238,944 & 994,823 & $1,766,003$ \\
\hline \multicolumn{8}{|c|}{ Non-Residential Sector Efficiency Resource } \\
\hline 1993 Prices & 21,201 & 4,665 & 2,236 & 64,426 & 488 & 399,503 & 466,674 \\
\hline Low Prices & 28,713 & 6,773 & 2,717 & 76,045 & 5,103 & 403,343 & 496,295 \\
\hline High Prices & 46,057 & 14,862 & 2,732 & 77,763 & 77,222 & 403,398 & 589,123 \\
\hline \multicolumn{8}{|c|}{ Non-Residential Sector Efficiency Resource as percent of Residential Use (\%) } \\
\hline 1993 Prices & 11 & 5 & 13 & 27 & 0 & 40 & 28 \\
\hline Low Prices & 16 & 7 & 15 & 32 & 2 & 41 & 30 \\
\hline High Prices & 25 & 16 & 15 & 33 & 32 & 41 & 35 \\
\hline
\end{tabular}

\subsection{Industrial Sector Efficiency}

This section presents an estimate of the industrial sector efficiency potential. These estimates are based upon the'professional judgment of Czech experts and comparisons with consumption levels from similar industries in other countries. These estimates are to be regarded as preliminary and would require significant effort to refine before using for decision-making purposes.

\subsubsection{Steel and Machine-Tool Industry}

This industry is the largest energy user in the industrial sector, consuming $2,355,425$ GJ per year, which is $58.28 \%$ of the energy demand of the sector. Heat energy is used for heating industrial and other buildings, operation of some equipment such as steam presses, heating in technological and production processes, and hot water for washing and cleaning.

Energy efficiency in this industry can be expected from implementing improvements to industrial building shells which typically have extremely low insulation or no insulation at all and high infiltration rates. Waste heat from industrial processes also can be utilized for adjacent manufacturing or office spaces and for preheating the process and utility water. Based on comparisons with results of many energy saving projects in the U.S. in similar environments, it can be expected that approximately an $18 \%$ reduction in heating energy saving can be accomplished. 


\subsubsection{Food Industry}

The largest representative of this group is the Pilsner Urquell Brewery. This sector consumes $1,142,541 \mathrm{GJ} / \mathrm{year}$, which represents $28.27 \%$ of industrial demand. Energy is mostly consumed by technological processes, space heating and utility water heating. Food processing is inherently demanding on hot water use for the process itself and mainly for washing the processed material, washing equipment, and general cleaning. Processes, such as those found in a brewery, also produce a great deal of waste heat.

Energy efficiency potential in this group can be expected mostly from utilization of waste heat for water preheating, and space heating. Preheating process water in heat recovery heat exchangers is currently being analyzed by the Brewery, and substantial efficiency improvements are expected. Efficiency estimates made by Czech experts predict reductions of $20 \%$ achievable through heat recovery.

\subsubsection{Pulp and Paper Industry}

Paper manufacturing processes are àlso inherently energy-demanding. Heat required for technological processes and space heating is about $431,1509 \mathrm{GJ} /$ year, or $10.68 \%$ of total industrial demand is consumed by the paper industry in Plzen.

Energy use can be also be reduced through the implementation of waste heat recovery in water and air systems. Application of heat recovery for very energy-demanding drying processes is currently being investigated. Czech experts and company engineers estimate energy use reductions of about $15 \%$.

\subsubsection{Other Industries}

Other industries, such as agricultural, manufacturing of building materials, and others, represent only a small part of this demand sector. Their combined consumption is $111,756 \mathrm{GJ} / \mathrm{year}$, which is $2.77 \%$ of total industrial demand. Efficiency potential may be significant relative to the industry's consumption, but compared to the entire industrial consumption, quite small. 



\subsection{Resource Acquisition}

Realization of the significant efficiency potential in the residential and non-residential buildings sectors cannot be achieved by market forces alone. The energy efficiency resource is typically capital intensive and distributed in nature, with the burden typically on the energy consumer to acquire the resource. This chapter presents a number of factors that inhibit the acquisition of the efficiency resource and discusses several options for overcoming these barriers.

\subsection{Resource Acquisition Barriers}

This subsection presents four factors that will inhibit the acquisition of the efficiency resource identified in the residential and non-residential buildings sectors. These factors bear most heavily on low-income consumers.

\subsubsection{Tenant Responsible for Energy Bill}

The tenant is often interested in reducing the energy bill, but is unwilling to invest in measures that become part of the building owner's property. In turn, the building owner, which may be a cooperative, often lacks a clear profit incentive to invest in efficiency measures that will reduce the tenant's energy bill. The ability to recoup efficiency investments to provide a lower energy bill is difficult in a free market situation, not to mention a market in which rents are controlled for nearly all buildings.

\subsubsection{Tenant Time Horizons}

Two factors limit tenant time horizons, thereby reducing tenant-financed investments in energy efficiency. The amount of discretionary money available to individuals, coupled with a desire for a very short payback, reduces voluntary investment in efficiency. Second, the residency period is decreasing for a large fraction of the high rise apartment buildings which contain a signification fraction of the efficiency resource, resulting in a reluctance to make an investment that will be lost.

\subsubsection{Insufficient Information}

There is a general lack of information regarding the application, performance and cost of energy efficiency measures. This represents a significant time and monetary cost to individuals and businesses interested in pursuing efficiency improvements.

\subsubsection{Lack of Capital}

The availability of capital to finance efficiency acquisition, much less satisfy many other investment needs during the economic transition, is limited. In addition, the cost of capital is quite high, especially for an individual or relatively small borrower. The current interest rate of about $20 \%$ for major borrowers covers the inflation rate of about $12 \%$, plus provides an approximate $8 \%$ real return to the lender. 


\subsubsection{Lack of Individual Meters}

There is a lack of meters to measure heat energy consumption at the building level, much less at the tenant level, so there is no reliable means to provide feedback to the tenant on actual consumption and to reflect this in the energy bill.

\subsection{Financing Options}

Two major options for financing the acquisition of the efficiency resource are utility-financed demand-side management (DSM) and third-party contracting. These two approaches tend to address the barriers identified above to provide economically efficient levels of investment in energy efficiency vs. energy supply on a levelized energy cost basis. A typical benefit of utility-financed programs is the usually lower cost of capital available to the utility, which in effect lowers the cost of the efficiency measures and increases the magnitude of the efficiency resource. Implementing either approach in the Czech Republic will require policy and regulatory changes.

\subsubsection{Utility-Financed DSM}

A growing trend in the U.S. is for utilities to provide energy services to their customers at the least cost. In this process, the utilities evaluate both demand and supply resources and finance the acquisition of both to provide customers with the lowest cost mix of energy resources. The prices of demand and supply resources are typically compared on a per unit basis, Kc/GJ, with the quantities of each based upon the lower of the two costs. The mechanics of the actual acquisition may be managed directly by the utility or subcontracted out to a third party or parties.

Utilities may finance the resource acquisition through use of cash reserves, issuance of stock and/or bonds, or loans from a financial institution. The cost of the efficiency resource is typically factored into the energy price, as is the cost of supply resources, in an amount sufficient to retire any debt incurred and to obtain an acceptable rate of return. In the case of private utilities, the ability to implement this least-cost approach is dependent upon the regulatory requirements and financial incentives provided. In addition to the economic benefits of this approach, environmental benefits accrue through the reductions in fuel extraction and combustion, and the utility's relationship and image with its customers is improved.

\subsubsection{Third-Party Contracting}

Businesses referred to as energy service companies (ESCOs) provide financing for and management of the resource acquisition activity. ESCOs usually self-finance projects or obtain funds from a financial institution to perform the project and earn an acceptable rate of return on the investment to repay the loan and secure a profit. ESCOs typically contract with the building owner and/or the utility to make the investment to obtain the energy efficiency upgrade in return for a share of the reduction in the energy bill. In some cases, the utility may provide an incentive program that contributes to the ESCO's return.

ESCOs provide a turnkey service to evaluate the efficiency potential for a project, finance the installation of the agreed-upon measures, specify and manage the installation of the measures, and may maintain and operate the facility to ensure the energy use reductions are achieved. The basis and term for repayment are negotiated, usually for a share of the energy bill reduction. 


\subsection{Other Facilitating Actions}

A number of facilitating actions are provided in this subsection that would contribute to the acquisition of the efficiency resource by reducing one or more of the identified barriers. The actions provided are not intended to be exhaustive, only to illustrate some obvious steps that could be taken to acquire the efficiency resource.

\subsubsection{Information Resource}

Availability of credible information on the application, performance and cost of efficiency actions would reduce the time and monetary cost to individuals and organizations interested in lowering their energy bills. One option would be for the municipal authority to initiate an information center; this could be carried out in cooperation with the various energy suppliers.

\subsubsection{Private Business Activities}

Municipal and consumer organizations could engage in a number of activities to foster greater private sector business activity. This may be through encouraging ESCO activity by promoting their services and/or working with lending institutions to enable availability of financial resources. Another encouraging mechanism would be to provide education and training to consumers and energy service providers.

\subsubsection{Policy Changes}

Municipal and consumer organizations could support changes to energy policy and utility regulation that will encourage the evaluation and acquisition of energy efficiency commensurate with supply resources. For example, policy and regulatory changes could address the utility planning process to require the use of least-cost principles; permit recovery of efficiency investments through rates; encourage financing and/or investment in energy efficiency projects; establish standards for minimum energy performance; and/or require the use of certain measures to reduce energy consumption. 


\subsection{Summary and Conclusions}

This report provides an assessment of the energy efficiency resource within the buildings sector space and water heat end-uses that exist in the municipality of Plzeñ, Czech Republic. Baseline energy consumption of total energy used by sector for the production of thermal energy is first accounted for. Buildings sector efficiency potential is estimated for the base period and alternate fuel price scenarios. Major issues to consider for the acquisition of the efficiency resource are then presented.

\subsection{Baseline Thermal Energy Consumption}

In 1989, the municipality of Plzen consumed about 20.9 million GJ of energy for the production of thermal energy. About $80 \%$ of the total energy consumed is in the form of solid fuels, primarily coal, followed by $17 \%$ in the form of gaseous fuels, and $3 \%$ as liquid fuels. About $69 \%$ of the City's thermal energy is consumed/delivered in the form of district heat, $21 \%$ is consumed in local boilers that serve a single building or small group of buildings, and $10 \%$ is consumed in on-site equipment located in the customers/occupants space.

Of the 20.9 million GJ, approximately $38 \%$ provided space and water heat for the building and industrial sectors, $20 \%$ was used for industrial and other process energy requirements, $3 \%$ for electricity generation, and $38 \%$ was lost in the production and transmission/distribution of thermal energy. Conversion and transmission losses in the district system are estimated to be $44 \%$ of energy input and for the local boilers equals about $25 \%$. Distribution losses for the district system were not estimated.

The breakdown of space and water heat by fuel and equipment type to the residential and nonresidential buildings sectors and the industrial sector is provided in Table 5.1. Nearly $38 \%$ of heat and hot water energy use is accounted for by the residential sector, about $23 \%$ by the non-residential buildings sector, and $38 \%$ by the industrial sector. District heat is the major energy source for heat and hot water at $64 \%$ of the total, followed by building boilers supplying at $18 \%$, and on-site conversion equipment at nearly $17 \%$.

Table 5.1. Baseline Space and Water Heat Energy Consumption (GJ) by Sector, Fuel Type and Equipment Type, 1989

\begin{tabular}{|c|c|c|c|c|c|c|c|}
\hline \multirow[b]{2}{*}{ Sector } & \multicolumn{3}{|c|}{ On-Site } & \multicolumn{2}{|c|}{ Boiler House } & \multirow{2}{*}{$\begin{array}{c}\text { District } \\
\text { Heat }\end{array}$} & \multirow[b]{2}{*}{ Total } \\
\hline & Gas & Coal & Electric & Gas & Coal & & \\
\hline Residential & 633,912 & 318,169 & $.47,690$ & 108,690 & 233,275 & $1,673,465$ & $3,015,201$ \\
\hline Non-Residential & 184,831 & 92,987 & 17,739 & 236,679 & 238,944 & 994,823 & $1,766,003$ \\
\hline Industrial & 25,538 & 46,493 & 8,870 & 290,239 & 176,989 & $2,359,975$ & $2,908,104$ \\
\hline Total & 844,281 & 457,649 & 74,299 & 635,608 & 649,208 & $5,028,263$ & $7,689,308$ \\
\hline
\end{tabular}




\subsubsection{Residential Sector}

As shown in Table 5.2, residential sector space heat accounts for nearly $80 \%$ of the total energy used for residential heat and hot water energy consumption. Of this amount, $54 \%$ is provided by the district system, and $34 \%$ is consumed on-site in the form of solid and gaseous fuels. Only about $10 \%$ of residential sector space heat energy is provided by local boilers and $1 \%$ by electricity. Residential sector hot water is also provided primarily by the district system (58\%), followed by gaseous fuels accounting for about $25 \%$ of total energy use; and solid fuels and electricity are about equal at $8 \%$ each. Electricity is used to a greater extent for hot water than for space heat in the residential sector.

Table 5.2. Residential Sector Space and Water Heat Energy Consumption (GJ) by Fuel and Equipment Type, 1989

\begin{tabular}{||l|r|r|r|r|r|r||}
\hline \multirow{2}{*}{ Fuel } & \multicolumn{2}{|c|}{ Space Heat } & \multicolumn{2}{c|}{ Water } & \multicolumn{2}{c|}{ Total } \\
\cline { 2 - 7 } & \multicolumn{1}{c|}{$(\mathbf{G J})$} & \multicolumn{1}{c|}{$(\%)$} & \multicolumn{1}{c|}{ (GJ) } & \multicolumn{1}{c|}{$(\%)$} & \multicolumn{1}{c|}{ (GJ) } & $(\%)$ \\
\hline \hline Solid Fuel - local & 318,169 & 13.18 & 0 & 0.00 & 318,169 & 10.44 \\
\hline Gaseous Fuel - local & 498,710 & 20.66 & 135,202 & 21.34 & 633,912 & 20.80 \\
\hline Boilers-Solid Fuel & 177,289 & 7.34 & 55,986 & 8.84 & 233,275 & 7.65 \\
\hline Boilers-Gaseous Fuel & 82,604 & 3.42 & 26,086 & 4.12 & 108,690 & 3.57 \\
\hline CHSS & $1,304,797$ & 54.06 & 368,668 & 58.18 & $1,673,465$ & 54.91 \\
\hline Electricity & 32,194 & 1.33 & 47,690 & 7.53 & 79,884 & 2.62 \\
\hline Total & $2,413,763$ & 100.00 & 633,632 & 100.00 & $3,047,395$ & 100.00 \\
\hline
\end{tabular}

The high rise multi-family building types, which account for about $51 \%$ of the total floorspace, consume about $55 \%$ of residential space heat energy use. These buildings are also predominantly served by district heat, which accounts for about $88 \%$ of their total heat energy use and $90 \%$ of the residential sector space heat consumption supplied by district heat. The remainder of the residential building stock is served primarily by home heating equipment fired by solid fuel and gaseous fuels, at $13 \%$ and $21 \%$ of total energy use, respectively. Local boilers account for about $10 \%$ of residential space heat energy consumption with solid and gaseous fuels at $7 \%$ and $3 \%$ of the residential total, respectively.

As with heat energy consumption, the four high rise building types account for the majority of energy use for hot water- $60 \%$ of the total hot water energy use. Of this amount, about $87 \%$ is provided by the district heating system and the remainder by natural gas and solid fuels, about $10 \%$ and $4 \%$, respectively. 


\section{Non-Residential Sector}

Education, office, and retail service buildings account for about $65 \%$ of total non-residential sector use, followed by health and lodging buildings that account for another $22 \%$ of heat and hot water usage. The remaining $13 \%$ of non-residential space and water heat energy consumption is in the gymnasium and culture building types.

District heat accounts for about $56 \%$ of total heat and hot water use, with education and office buildings accounting for over $68 \%$ of district-system-supplied energy. Individual boilers provide the next largest share of heat and hot water, $27 \%$; which is split nearly equally between solid and gaseous fuels. On-site equipment accounts for the remaining $16 \%$ of energy consumption, two-thirds of which is supplied by gaseous fuels.

\subsection{Efficiency Assessment}

Fifty energy conservation opportunities (ECOs) were considered for evaluation for the residential and non-residential building stock in Plzeň. Of these, 24 ECOs were determined to be applicable to more than one building group and were analysed with respect to energy efficiency potential, cost and availability on the Czech market. Eleven of the measures applied to the building envelope, 4 to water heating, 6 to the heating system, and 3 to ventilation and heat recovery.

The measures were analyzed for each residential building type and fuel and heating system type to calculate their technical and economic performance for current fuel prices and two fuel price scenarios. The low price scenario corresponds to the removal of subsidies and the high price scenario corresponds roughly to Western European fuel prices. This analysis was then translated to the non-residential building types to estimate their efficiency potential.

Measures had to display a positive net present value in order to be selected for application. Based upon the positive NPV criteria, the following group of seven measures having interactive effects on . energy use reductions were selected for application:

- Insulate building exterior side walls

- Weatherstrip elevator penthouse, stairway, doors and windows

- Weatherstrip windows and doors

- Install revolving or double door in vestibule

- Install storm windows

- Install zone valves on each radiator and install central thermostats with 'on-time counter' in each apartment

- Install heat recovery vent system in basements.

Depending upon the building type, a subset of these items was selected based upon their combined performance and NPV. 
The following seven measures which did not exhibit interactive effects were also selected for application depending on their performance and NPV:

- Install heat reflectors behind each radiator or heater

- Remove draperies from radiator

- Install low-flow shower heads

- Install flow restrictors on faucets

- Insulate hot water pipes in unconditioned spaces

- Install hot water flow meters

- Install waste water heat recovery heat exchanger.

Table 5.3 provides the residential and non-residential cost-effective efficiency resource by fuel and heating equipment type by fuel price scenario. This shows the level of resource increasing from $27 \%$ of baseline energy use in the low price scenario to $34 \%$ in the high fuel price scenario.

About $80 \%$ of the efficiency resource resides in the district heating area for the current and low price scenarios; this drops to $66 \%$ of the efficiency resource in the high price scenarios. Space and hot water heat provided by gaseous fuels is the next largest resource, increasing from $15 \%$ of the resource under current prices to $20 \%$ in the high price scenario. The coal resource increases significantly from

Table 5.3. Residential and Non-Residential Sector Space and Water Heat Efficiency Improvement by Fuel and Equipment Type for Current and Projected Fuel Prices and as a Percent of Total Residential and Non-Residential Consumption

\begin{tabular}{|c|c|c|c|c|c|c|c|}
\hline \multirow[b]{2}{*}{ Sector } & \multicolumn{3}{|c|}{ On-Site } & \multicolumn{2}{|c|}{ Boiler House } & \multirow{2}{*}{$\begin{array}{c}\text { District } \\
\text { Heat }\end{array}$} & \multirow[b]{2}{*}{ Total } \\
\hline & Gas & Coal & Electric & Gas & Coal & & \\
\hline \multicolumn{8}{|c|}{ Residential and Non-Residential Efficiency Resource (GJ) } \\
\hline 1993 Prices & 93,912 & 20,627 & 8,258 & 94,012 & 964 & 1,071536 & $1,298,299$ \\
\hline Low Prices & 127,192 & 29,946 & 10,023 & 110,968 & 10,084 & $1,081,836$ & $1,370,048$ \\
\hline High Prices & 204,019 & 65,715 & 10,075 & 113,474 & 152,612 & $1,081,982$ & $1,627,877$ \\
\hline \multicolumn{8}{|c|}{ Residential and Non-Residential Efficiency Resource as a Percent of Residential and Non-Residential Use (\%) } \\
\hline 1993 Prices & 11 & 5 & 13 & 27 & 0 & 40 & 27 \\
\hline Low Prices & 16 & 7 & 15 & 32 & 2 & 41 & 29 \\
\hline High Prices & 25 & 16 & 15 & 33 & 32 & 41 & 34 \\
\hline
\end{tabular}


$2 \%$ of the total resource at 1993 prices to $13 \%$ of the total efficiency resource under the high fuel price scenario. The electricity resource is projected to be the least sensitive to fuel prices and the least significant at less than $1 \%$ of the total for all price levels.

Nearly $80 \%$ of the residential sector efficiency resource is in the high-rise multi-family building types, and of this, $98 \%$ is in the district heating area under current fuel prices. Under the high fuel price scenarios, about $70 \%$ of the residential sector efficiency resource is in the high-rise building types, of which $90 \%$ is in the district heating area. In the non-residential sector, about $65 \%$ of the efficiency potential resides in the education, office and retail building types under all three fuel price scenarios. The share of the efficiency potential in the education, office and retail building types accounted for by the district heat area is $83 \%, 80 \%$, and $68 \%$ for the 1993 , low, and high fuel price scenarios, respectively.

\subsection{Resource Acquisition Issues}

The ability to realize the buildings sector efficiency potential identified will require that several issues, which serve as disincentives or barriers to acquiring the efficiency potential, will be addressed and resolved.

\subsubsection{The Issues}

Renters and building owners are faced primarily with economic disincentives to invest in energy efficiency. Building occupants and tenants who pay rent do not have the incentive to invest in efficiency because efficiency measures become a part of the building, hence the landlord's property. If the tenants were to move, they lose both the investment and the benefit of the lower energy bill. Landlords are faced with rent controls, which prevent them from reflecting the benefit of lower energy bills in the rent. Finally, given the lack of funding sources available to finance such investments, especially by relatively small borrowers, and the high interest rates, borrowers require a short payback on an investment.

Comprehensive and credible information for consumers regarding the cost and performance of applicable technologies' is also lacking. This poses a cost in time and money for individuals, businesses, and other organizations to understand what measures work best in different applications.

A lack of institutional mechanisms and financing to support energy efficiency pose the most significant obstacle to acquiring the resource. Neither utility-operated programs nor an energy services company industry exist to implement energy efficiency measures. This, coupled with the lack of an identifiable lending resource, will likely prevent serious efforts to acquire the efficiency resource if the situation remains unchanged.

\subsubsection{Addressing the Issues}

The economic issues facing renters and landlords are common in market economies and are not easily resolved. The opportunity to address the information, institutional and financing issues is available in the current period in which restructuring is taking place. Information resources can be established with the support of government, private sector and other non-government organizations at a nominal cost. Institutional processes can be put in place through policies, regulations and operating requirements to enable and encourage utilities to plan for and manage the delivery of efficiency 
programs. Policy and regulatory reforms can be structured to enable governmental and/or utilityoriginated financing and to reduce the risk of loan repayment to non-governmental lending institutions.

\subsection{Conclusions}

A major purpose of this study is to assess the energy efficiency potential that exists in the buildings sector space and water heat end-uses. Subject to the data limitations and assumptions made, a significant efficiency resource appears to exist in the space and water heating end-uses in the residential and non-residential buildings sectors. At current prices, this resource amounts to $12 \%$ of total buildings sector space and water heat energy consumption and increases to $29 \%$ and $33 \%$ of buildings sector consumption in two scenarios in which energy price controls and subsidies are relaxed.

About $90 \%$ of the efficiency resource resides in the district heating area for the current and low price scenarios; this drops to $80 \%$ of the efficiency resource in the high price scenarios. Space and hot water heat provided by gaseous fuels is the next largest resource, increasing from 7\% of the resource under current prices to $18 \%$ in the high price scenario. While coal consumption for local boiler and onsite consumption is expected to increase significantly, it still accounts for less than $3 \%$ of the total efficiency resource under the high fuel price scenario. Electricity consumption is projected to be the least sensitive to fuel prices, but the efficiency resource is $1 \%$ or less of the total.

Nearly $90 \%$ of the residential sector efficiency resource is in the high rise multi-family building types. Of this, $89 \%$ is in the district heating area under current prices and $75 \%$ under the high price scenario. In the non-residential sector, nearly $70 \%$ of the efficiency potential resides in the education, office and retail building types, with $93 \%$ of this in the district heating area under current prices and dropping to $80 \%$ in the high price scenario.

The combination of the four building types (high-rise multi-family, education, office, and retail) served by district heat contains nearly $80 \%$ of the total buildings sector space and water heat efficiency potential under current prices; this decreases to about $70 \%$ in the high price scenario. Acquisition of this potential alone would result in a $10 \%$ to $20 \%$ reduction in buildings sector space and water heat energy consumption.

The levelized energy cost of the total efficiency resource is about $105 \mathrm{Kc} / \mathrm{GJ}$ compared to the current consumption weighted average energy price of $103 \mathrm{Kc} / \mathrm{GJ}$. At the low and high consumption weighted prices of $152 \mathrm{Kc} / \mathrm{GJ}$ and $286 \mathrm{Kc} / \mathrm{GJ}$ in the low and high price scenarios, the levelized energy cost is about $137 \mathrm{Kc} / \mathrm{GJ}$. Under current prices, the levelized energy cost of the efficiency resource within the district system fuel type is about $112 \mathrm{Kc} / \mathrm{GJ}$ compared to $136 \mathrm{Kc} / \mathrm{GJ}$ for district heat. Under the respective low- and high-price scenarios, district heat is projected to increase to $200 \mathrm{Kc} / \mathrm{GJ}$ and $350 \mathrm{Kc} / \mathrm{GJ}$ compared to a levelized energy cost for the district-heat-based efficiency resource of $146 \mathrm{Kc} / \mathrm{GJ}$.

Under two future consumption scenarios and in absence of actions to acquire energy efficiency, buildings sector space and water heat energy consumption are projected to increase by $1 \%$ to $6 \%$ overall by the year 2003. Depending upon changes in fuel prices, buildings sector space and water heat energy consumption could decrease about $6 \%$ to $27 \%$ if the entire resource were acquired. A more modest efficiency resource acquisition effort could easily provide a $0 \%$ increase in buildings sector space and water heat consumption. 
The ability to acquire the resource is limited primarily by the absence of institutional mechanisms set up to do so and by the limited availability of financing. These issues can be addressed through policy and regulatory changes to provide the institutional structures and incentives in conjunction with commitment and leadership to address them. 



\subsection{Related Publications}

This report is one of four containing an energy assessment of options for upgrading the district heating system for the City of Plzen, Czech Republic:

An Evaluation of the Supply-Side Options for the Plzeñ District Heating System (Gilbert/Commonwealth)

Assessment of the Buildings Sector Efficiency Resource for the City of Plzen̆ (Pacifịc Northwest National Laboratory)

Efficiency and Supply Resource Options for the Upgrade of the Plzeñ District Heating System (Pacific Northwest National Laboratory)

Heat Supply in Plzeñ: Final Report (SEVEn, Pacific Northwest National Laboratory)

All of these reports were published by

Pacific Northwest National Laboratory

901 D Street S.W., Suite 900

Washington, DC 20024-2115. 